\title{
Variability of circulation features in the Gulf of Lion NW Mediterranean Sea. Importance of inertial currents
}

\section{Variabilité de la circulation dans le golfe du Lion (Méditerranée nord-occidentale). Importance des courants d'inertie}

\author{
Anne A. Petrenko * \\ Centre d'Océanologie de Marseille, LOB-UMR 6535, Faculté des Sciences de Luminy, 13288 Marseille cedex 09, France
}

Received 9 October 2001; revised 5 July 2002; accepted 18 July 2002

\begin{abstract}
ADCP data from two cruises, Moogli 2 (June 1998) and Moogli 3 (January 1999), show the variability of the circulation features in the Gulf of Lion, NW Mediterranean Sea. The objective of the present study is to determine whether the hydrodynamic features are due to local forcings or seasonal ones. During both cruises, the Mediterranean Northern Current (NC) is clearly detected along the continental slope and intrudes on the eastern side of the shelf. East of the gulf, its flux is $\sim 2 \mathrm{~Sv}$ both in June and January in opposition to previous literature results. Otherwise, the NC characteristics exhibit usual seasonal differences. During the summer, the NC is wider (35 km), shallower ( 200 m), and weaker (maximum currents of 40-50 $\mathrm{cm} \mathrm{s}^{-1}$ ) than during the winter (respectively, $28 \mathrm{~km}, 250-300 \mathrm{~m}, 70 \mathrm{~cm} \mathrm{~s}^{-1}$ ). Moreover the NC is tilted vertically during the winter, following the more pronounced cyclonic dome structure of that season. Its meanders are interpreted as due to baroclinic instabilities propagating along the shelf break. Other circulation features are also season-specific. The summer stratification allows the development, after strong wind variations, of inertial currents with their characteristic two-layer baroclinic structure. In the top layer, the speed of the inertial oscillation can locally be as high as $200 \%$ the $\mathrm{NC}$ speed. Otherwise in the surface layer, inertial current is about $2 / 3$ the NC. During the 1999 winter, dense water formations are observed both on the continental shelf and offshore. Other hydrodynamic features depend primarily on topography or wind forcing. Deep portions of the NC go up canyons. The continental shelf circulation is complex, and influenced by the wind stress curl. During Moogli 3, strong eastern counter-currents may be linked to the numerous intrusions of the NC on the shelf. During Moogli 2, tramontane conditions seem to favor the formation of a cyclonic structure on the western continental shelf.
\end{abstract}

(C) 2003 Éditions scientifiques et médicales Elsevier SAS and Ifremer/CNRS/IRD. All rights reserved.

\section{Résumé}

Les données ADCP de Moogli 2 (juin 1998) et Moogli 3 (janvier 1999) montrent la variabilité de la circulation dans le golfe du Lion, (Méditerranée nord-occidentale). L'objectif est de déterminer si les structures dynamiques sont dues aux forçages locaux ou saisonniers. Durant les deux campagnes, le courant Nord longe le talus continental, et, en amont, a un flux de $\sim 2 \mathrm{~Sv}$. Sinon, ses caractéristiques habituelles sont opposées entre les deux saisons. En juin, le courant Nord est plus large (35 km), moins profond ( 200 m), et plus faible (maximum de $40-50 \mathrm{~cm} \mathrm{~s}^{-1}$ ) qu'en janvier (respectivement, $28 \mathrm{~km}, 250-300 \mathrm{~m}, 70 \mathrm{~cm} \mathrm{~s}^{-1}$ ). Le courant Nord est incliné verticalement en hiver, suivant les pentes isopycnales de la structure en dôme, plus marquées en cette saison. Les méandres du courant Nord sont dus à des instabilités baroclines se propageant le long du talus continental. D'autres structures de circulation sont aussi saisonnières. La stratification estivale permet le développement, après un fort épisode de vent, de courants inertiels, baroclines à 2 couches. Dans la couche supérieure, leur vitesse peut s'élever localement à $200 \%$ la vitesse du courant Nord. Sinon, dans la couche de surface, le courant inertiel représente $2 / 3$ du courant Nord. Pendant l'hiver 1999, des formations d'eaux denses ont été observées sur le plateau continental et au large. D'autres structures hydrodynamiques sont forcées par la topographie ou le vent. Les parties profondes du courant Nord remontent certains canyons. La circulation du plateau est complexe, influencée par le rotationnel du vent. Durant Moogli 3, de forts contre-courants vers l'est sont peut-être liés aux intrusions du courant Nord sur le plateau. Durant Moogli 2, la tramontane semble favoriser une circulation cyclonique à l'ouest du plateau.

(C) 2003 Éditions scientifiques et médicales Elsevier SAS and Ifremer/CNRS/IRD. All rights reserved.

\footnotetext{
* Corresponding author.

E-mail address: petrenko@com.univ-mrs.fr (A.A. Petrenko).
} 
Keywords: Coastal circulation; Inertial oscillations; Forcings

Mots clés : Circulation côtière ; Oscillations inertielles ; Forcages

\section{Introduction}

There is a renewal of interest in coastal circulation due to the increasing population along coasts all over the world, the potentially accompanying rise in pollution, and the parallel growth in environmental concerns. Coastal areas and their terrestrial inputs can favor phytoplankton activity (Cruzado and Velasquez, 1990), and hence affect global budgets of biogeochemical elements, such as some greenhouse gases. To be able to forecast these parameters both on short (and local) and long (and global) scales, there is still a need for in situ physical and biogeochemical measurements, their analysis, and their use in adequate modeling. This is being undertaken for the Gulf of Lion, an extended continental shelf in the northern western Mediterranean Sea, between Cap Creus, Spain, and Marseilles, France (Fig. 1). Unless explicitly mentioned, the Gulf of Lion (GoL) will refer, in this article, not only to the continental shelf, but also to its adjacent continental slope. This paper will focus on circulation features detected in ADCP measurements during two oceanographic cruises, Moogli 2 and Moogli 3 modeling and observing the GoL. These cruises were performed, respectively, in June 1998 and January 1999 in the GoL.

The meteorological forcing is important in the GoL. Due to the surrounding orography, continental winds-when they occur-are mainly channeled in two directions: the tramontane from the west/northwest, and the mistral from the north. They can occur together, the tramontane on the western side of the GoL and the mistral on the eastern side. They generate

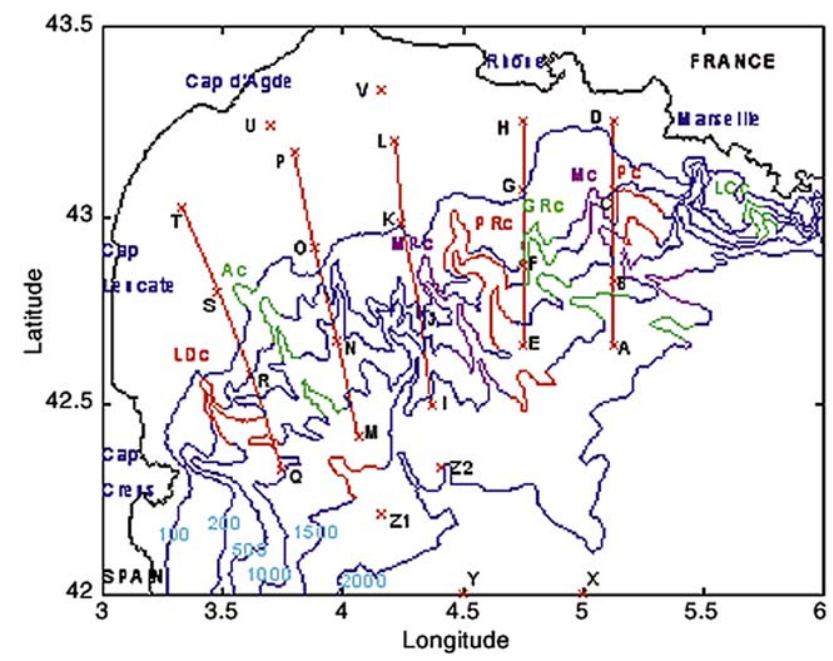

Fig. 1. Map of the GoL. Moogli stations are indicated by crosses. The five main transects correspond to AD, EH, IL, MP, and QT. Isobaths at 100, 200, 500, 1000, 1500, $2000 \mathrm{~m}$ are drawn. Canyons locations and names (at the canyon head) are in the same color. From west to east, the canyons are: LDc $=$ Lacaze-Duthiers; Ac $=$ Aude $;$ MPc $=$ Montpellier; PRc $=$ Petit Rhône; GRc $=$ Grand Rhône; $\mathrm{Mc}=$ Marseille; Pc $=$ Planier; and LCc $=$ La Ciotat canyon. upwellings (Millot, 1982), downwellings, and inertial currents (Millot, 1990). Otherwise, southeasterly winds can be strong from autumn to spring.

River discharges are also important on that continental shelf. The Rhone River accounts for roughly $90 \%$ of the total fresh water input in the GoL (Fieux, 1974). Its mean flow rate has been estimated close to $1700 \mathrm{~m}^{3} \mathrm{~s}^{-1}$ over a 30 year period (Moutin et al., 1998); but its flux can vary by a factor of 2 during the year (higher in autumn and spring).

The main general circulation feature influencing the $\mathrm{GoL}$ is the Northern Current (NC) (Millot, 1991). The evaporation-induced water deficit in the Mediterranean Sea generates a surface flux of Atlantic waters through the Gibraltar Strait (Lacombe and Tchernia, 1960). Due to the Coriolis force and the basin bathymetry, these waters tend to flow-not taking into account instabilities-cyclonically around the western basin (Millot, 1999). The NC follows the cyclonic curve on the northern side of the basin, hence north of an isopycnal dome structure (Lacombe and Tchernia, 1972). In the Ligurian Sea, the geostrophic NC flux (calculated to $700 \mathrm{dbar}$ ) varies throughout the year, in a range of $0.9-1.8 \mathrm{~Sv}$ with its maximum in November or December (Albérola et al., 1995; Sammari et al., 1995). Values up to 2.7 Sv were obtained in January 82 (Béthoux et al., 1988). Less flux studies have been done in the GoL than in the Ligurian Sea. Along longitude $5^{\circ} 12.5 \mathrm{E}, \mathrm{NC}$ flux reached extreme values, a maximum of $1.8 \mathrm{~Sv}$ in April 92 and a minimum of $0.5 \mathrm{~Sv}$ in June 92 (Conan and Millot, 1995). All these fluxes have been evaluated from geostrophic calculations. In this region, no fluxes calculated from ADCP data has been found in the literature. ADCP fluxes of $\sim 1 \mathrm{~Sv}$ were obtained in the northern Catalan Sea in spring 89 (Castellon et al., 1990). At longitude $5^{\circ} 12.5 \mathrm{E}$, the $\mathrm{NC}$ was found to be deep $(\sim 450 \mathrm{~m})$, narrow $(20-30 \mathrm{~km})$, quick $\left(0.50-1 \mathrm{~m} \mathrm{~s}^{-1}\right)$ and close to the coast in winter/spring and the opposite: shallow $(\sim 250 \mathrm{~m})$, wide $(\sim 40 \mathrm{~km})$, slow $\left(10-15 \mathrm{~cm} \mathrm{~s}^{-1}\right)$ and further from the coast in summer (Conan and Millot, 1995). Coming from the Ligurian Sea, the NC encounters the shelf break of the GoL on its northern side. There, it can either continue its route along the continental slope or split into two branches, the main one following the continental slope and the other entering the GoL (Echevin et al., in press; Millot and Wald, 1980). Its main branch can exhibit strong meanders (Albérola et al., 1995; Crepon et al., 1982; Flexas et al., 2002; Sammari et al., 1995).

Offshore the GoL, from surface to bottom, the following water masses can be found: the Modified Atlantic Water (MAW), the Western Mediterranean Intermediate Water (when and if present), the Levantine Intermediate Water (LIW), the Western Mediterranean Deep Water. They have different water mass characteristics but all flow cyclonically 
(Millot, 1999), with a speed continuum so that, when studying current measurements, no current shear clearly shows the limits of the NC. Hence, depending on authors, the NC refers to either all these water masses or uniquely to the MAW (Conan and Millot, 1995). Here, ADCP measurements going down to $400 \mathrm{~m}$ maximum, only MAW and LIW are observed in this depth range. But, in this paper, the NC will be defined, not according to water mass characteristics, but as the vein of strong western current with a lower magnitude limit of $0.05 \mathrm{~m} \mathrm{~s}^{-1}$.

Millot (1990) described the main hydrodynamic processes occurring in the GoL including inertial oscillatory currents. At the surface, horizontal inertial motions were coherent over distance of 14-43 km (Millot and Crepon, 1981). Millot and Crepon (1981) were able to demonstrate, with the analysis of current and temperature time series measured only at one point, that the inertial currents were propagating from the coast to the center of the GoL. In current time series collected near the shelf break offshore of the Ebro River, inertial motions clearly occurred in spring and summer, with amplitude ranges of $0.15 \mathrm{~m} \mathrm{~s}^{-1}$ even at $100 \mathrm{~m}$ depth (Font et al., 1995). Nonetheless, no example of the respective contributions of inertial currents versus mesoscale circulation has yet been found in the literature.

The numerous articles cited above prove that the GoL hydrodynamic features have been quite studied. But no studies with ADCP (acoustic Doppler current profilers) current measurements covering the whole gulf at two different seasons were done before the Moogli cruises. The main circulation features of each cruise will be detailed in Section 3. Similarities and differences will be explained in Section 4. Emphasis is put on differentiating the seasonal variability of these hydrodynamic features from the variability due to local forcings. The main findings of this descriptive article are summarized at the end. They include a quantification of inertial currents, along with recommendations on experimental and numerical work.

\section{Methods}

The main objective of the Moogli cruises was to establish biogeochemical budgets in the GoL, especially a carbon budget in order to determine whether the gulf acts as a carbon source or sink. Four oceanographic cruises had been planned so that the four main seasons be sampled in the gulf. The first Moogli cruise, Moogli 1, coupled with the atmospheric campaign Fetch, took place in spring March 1998. The second and third cruises took place on board of the R/V Le Suroit in June 1998 for Moogli 2, and in January 1999 for Moogli 3 (Fig. 1). The fourth cruise, planned for fall 1999, did not take place due to unfinished ship upgrading.

Moogli 2 started on June 3 and ended on June 19, 1998. The cruise was interrupted for $4 \mathrm{~d}$ (June 9-13) due to very bad meteorological conditions. Despite the fact that Moogli 2 took place in late spring/early summer, it will be referred to as "summer" cruise. Some of the observed circulation fea- tures, the seasonal ones, are expected to develop more in the hot season, when the stratification of the water column generally continues to increase. Moogli 3 took place from January 11 to January $21,1999$.

During these two cruises, continuous measurements were made with a RD Instruments hull-mounted ADCP and a Seabird thermosalinograph connected to an underway pump. At pre-chosen stations (A to T, Fig. 1), CTD profiles, Niskin samples, and sediment cores were collected or measured. These 20 stations are aligned on five transects, approximately orthogonal to both the coast and the continental slope (neglecting the various canyons) (Fig. 1). The study of physical processes was not the priority in the strategy of the cruises. Hence the cruise tracks were quite complicated during both cruises (Fig. 2a,c) due to sediment core sampling constraints. Moreover, stations or transects were added when judged necessary by the chief scientist.

The ADCP is a narrowband VM $150 \mathrm{kHz}$. The same configuration was used during both cruises: 50 cells, $8 \mathrm{~m}$ depth bins, an ensemble average of $2 \mathrm{~min}$ (120 pings), and no bottom tracking. Data analysis was done with RDI software CODAS (http://currents.soest.hawaii.edu/software/codas3/). The ADCP head alignment in the horizontal plane was corrected with the water tracking calibration method based on rapid changes in ship velocities (Joyce, 1989; Pollard and Read, 1989). The reference layer covered bins 2-14, corresponding to the depth range $24-120 \mathrm{~m}$. The correction factors found were an amplitude factor A of 0.9965 (1.007) and a correction angle $\phi$ of $3.3^{\circ}\left(3.8^{\circ}\right)$ for Moogli 2 (Moogli 3 ). The calibration is made before the ship velocity is retrieved; otherwise, the errors in the ADCP head alignment cause a part of the ship velocity component to be left in the current estimates. Once the corrections applied and the ship velocity retrieved, the final data are the horizontal currents, every $8 \mathrm{~m}$ from 16 to $408 \mathrm{~m}$ depth, given in a rectangular coordinate system where $x$ is pointing eastward and $y$ northward. Precision is better than $2 \mathrm{~cm} \mathrm{~s}^{-1}$ (theoretically, $1.5 \mathrm{~cm} \mathrm{~s}^{-1}$ ). Currents are also sometimes given in a polar coordinate system where the angle increases clockwise from the northern direction. During Moogli 2, the gyrocompass of Le Suroît was badly connected until mid-afternoon of June 6; hence the ADCP data could only be analyzed and calibrated correctly afterwards.

No time or distance averaging has been done on the ADCP data, unless specified otherwise. To facilitate understanding, current data are plotted only on specific chosen transects (Fig. 2b,d; Tables 1 and 2). Fluxes of the NC are calculated through surfaces orthogonal to the main flow. Direction of this main flow is obtained by averaging the directions of the currents in the main vein of the NC $\left(|\mathrm{V}|>10 \mathrm{~cm} \mathrm{~s}^{-1}\right)$. Then fluxes are calculated summing all the normal component of horizontal currents (with a lower limit $|\mathrm{V}|>0 \mathrm{~cm} \mathrm{~s}^{-1}$ ) by each unit surface. The flux is given in $\operatorname{Sv}\left(1\right.$ Sverdrup $=10^{6} \mathrm{~m}^{3} \mathrm{~s}^{-1}$ ), the surface in square kilometer, and a flux per unit surface is calculated (in $\mathrm{Sv} / \mathrm{km}^{2}$ ). Incertitude on the flux calculation, due to the ADCP precision limit of $2 \mathrm{~cm} \mathrm{~s}^{-1}$, is estimated by 

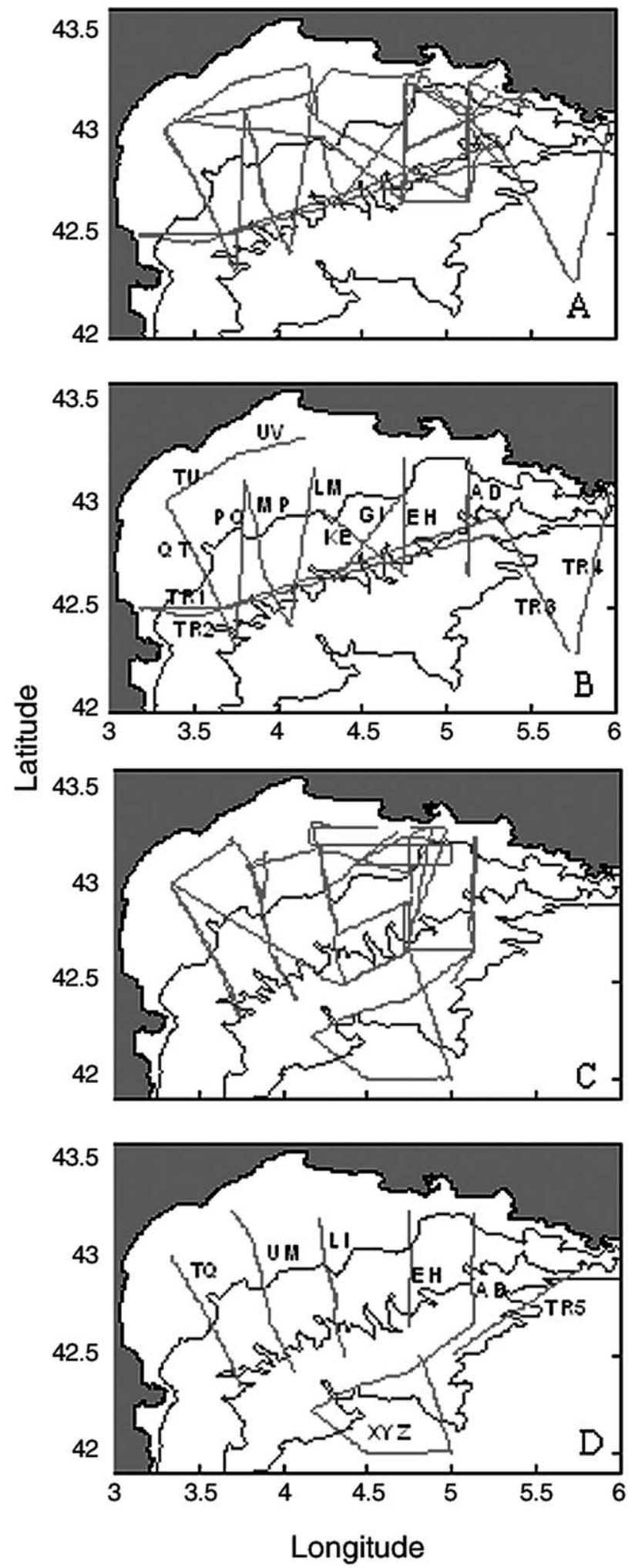

Fig. 2. Cruise tracks during (A) Moogli 2, (C) Moogli 3. Transects along which ADCP data are detailed for (B) Moogli 2, (D) Moogli 3. Isobaths 100, 1000 , and $2000 \mathrm{~m}$ are drawn.

multiplying the surface by $2 \mathrm{~cm} \mathrm{~s}^{-1}$, and is hence linearly proportional to the surface. Flux calculations were also done with a lower limit $|\mathrm{V}|>5 \mathrm{~cm} \mathrm{~s}^{-1}$. These fluxes were smaller
$(-2.8 \%$ in average, $\min =-0.5 \% ; \max =-7.9 \% ; \mathrm{std}=2.8 \%)$ than the fluxes calculated with the 0 limit; the fluxes per unit surface larger $(+10.6 \%$ in average, $\min =2.8 \%$; $\max =21.5 \%$; std $=7.4 \%$ ) than their counterparts; and the surfaces obviously smaller. Only the zero limit fluxes are shown, for easier comparison with literature values.

Wind amplitude and direction, $10 \mathrm{~m}$ above sea level, were measured on the ship. But to better evaluate the wind forcing, a wind data spatial coverage larger than just the ship track is required. Hence, winds modeled by the weather-forecast model Aladin (Météo-France) with a $6 \mathrm{~h}$ averaged period, on a $0.1^{\circ}-0.1^{\circ}$ grid throughout the gulf, were also used. Excellent agreement was found between measured and modeled winds during Moogli 1 (Estournel et al., in press). So, Aladin data were used here to provide the wind coverage throughout the gulf. The "Companie Nationale du Rhone" graciously provided daily flux of the Grand Rhone measured at Beaucaire, the station closer $(56 \mathrm{~km})$ to the river outlet.

\section{Results}

The results of the summer cruise Moogli 2 are shown in the first section, the ones of the winter cruise Moogli 3 in the second section.

\subsection{Moogli 2}

The external forcings are average for the season. During the cruise, the Rhone River mean flux is around $1600 \mathrm{~m}^{3} \mathrm{~s}^{-1}$ with a maximum flux about $1860 \mathrm{~m}^{3} \mathrm{~s}^{-1}$ on June 13. The wind blows from the east at the beginning of the cruise, then changes to a mistral/tramontane, with a big storm between June 10 and 13.

\subsubsection{The Northern Current (NC)}

3.1.1.1. Characteristics. During the cruise, the strongest currents are around $40-50 \mathrm{~cm} \mathrm{~s}^{-1}$ (Fig. 3a,d). They are located in the $50 \mathrm{~m}(100 \mathrm{~m})$ top layer along the eastern (western) continental slope and correspond to the core of the NC. Indeed the main branch of the $\mathrm{NC}$ follows the continental slope and is between 100 and $200 \mathrm{~m}$ deep (Figs. 3 and 4; Table 3). The width of the NC is hard to estimate when the transects do not extend south enough, seaward, to allow the detection of the outer edge of the NC (fig. 4). When the whole $\mathrm{NC}$ is crossed, flux varies from $2 \mathrm{~Sv}$ east of the GoL, $0.8 \mathrm{~Sv}$ across transect TR3, and $1.5 \mathrm{~Sv}$ in the western GoL (Table 4). The flux measured across transect $\mathrm{AD}$ is low $(0.4 \mathrm{~Sv})$ because the main branch of the NC is probably southward of the transect (Fig. 4 and explanations below).

3.1.1.2. Path and ramifications of the NC. The NC comes from the Ligurian Sea. About longitude $5.8^{\circ} \mathrm{E}$, it spreads on nearly $75 \mathrm{~km}\left(42.5^{\circ} \mathrm{N}\right.$ to the coast $43.17^{\circ} \mathrm{N}$; see transect TR4, Figs. 3a and 5). It then probably divides into a northern branch entering the GoL (NCb1, Fig. 6b) and a main branch 
Table 1

For each transect of Moogli 2, the table includes: the start day of the transect (and end day, if different), the start and end times of the transect, the start and end positions: latitude $\left({ }^{\circ} \mathrm{N}\right)$ and longitude $\left({ }^{\circ} \mathrm{E}\right)$, and the wind direction and strength (knots). Transects are classified in chronological order. Transects names refer to the stations at the extremities of the transect. For transect not linking two stations, TRi was used with $i=1,4$

\begin{tabular}{|c|c|c|c|c|c|c|}
\hline Transect & Day (06/98) & Time & Position start & Position end & Wind direction & Wind strength \\
\hline LM & 06 & $3: 50-21: 05$ & $43^{\circ} 12-4^{\circ} 13$ & $42^{\circ} 25-4^{\circ} 04$ & NW & 10 \\
\hline MP & $06-07$ & $21: 40-3: 20$ & $42^{\circ} 25-4^{\circ} 04$ & $43^{\circ} 07-3^{\circ} 48$ & NW & 10 \\
\hline PQ & 07 & $3: 25-21: 05$ & $43^{\circ} 07-3^{\circ} 48$ & $42^{\circ} 20-3^{\circ} 45$ & $\mathrm{~W}$ & 22 \\
\hline QT & 07-08 & $21: 35-4: 05$ & $42^{\circ} 20-3^{\circ} 45$ & $43^{\circ} 01-3^{\circ} 20$ & $\mathrm{~W}-\mathrm{NW}$ & $25-30$ \\
\hline TU-UV & 08 & $16: 35-21: 31$ & $43^{\circ} 01-3^{\circ} 20$ & $43^{\circ} 20-4^{\circ} 10$ & $\mathrm{~W}(\mathrm{~N})$ & $20(15)$ \\
\hline TR1 & $15-16$ & $20: 54-7: 06$ & $42^{\circ} 56-5^{\circ} 17$ & $42^{\circ} 30-3^{\circ} 11$ & $\mathrm{~N}-\mathrm{NE}$ & $20-25$ \\
\hline TR2 & 16 & $10: 34-20: 35$ & $42^{\circ} 30-3^{\circ} 11$ & $42^{\circ} 52-5^{\circ} 18$ & $\mathrm{~N}-\mathrm{NW}$ & 30 \\
\hline GI & 17 & $5: 15-10: 15$ & $43^{\circ} 04-4^{\circ} 45$ & $42^{\circ} 30-4^{\circ} 22$ & $\mathrm{~N}$ & $35-40$ \\
\hline $\mathrm{KE}$ & 17 & $14: 17-19: 39$ & $42^{\circ} 59-4^{\circ} 15$ & $42^{\circ} 40-4^{\circ} 45$ & $\mathrm{~N}$ & $20-25$ \\
\hline $\mathrm{EH}$ & $17-18$ & $20: 15-00: 45$ & $42^{\circ} 40-4^{\circ} 45$ & $43^{\circ} 15-4^{\circ} 45$ & $\mathrm{~N}$ & $20-30$ \\
\hline $\mathrm{AD}$ & 18 & $6: 15-11: 35$ & $42^{\circ} 40-5^{\circ} 08$ & $43^{\circ} 15-5^{\circ} 08$ & $\mathrm{NE}$ & $15-20$ \\
\hline TR3 & $18-19$ & $21: 55-2: 15$ & $42^{\circ} 59-5^{\circ} 19$ & $42^{\circ} 17-5^{\circ} 45$ & NW & $15-20$ \\
\hline TR4 & 19 & $2: 25-6: 35$ & $42^{\circ} 17-5^{\circ} 46$ & $43^{\circ} 04-5^{\circ} 58$ & NW & 15 \\
\hline
\end{tabular}

going southwest along the continental slope (transect TR3; Fig. 5). One fourth of the NC flux on transect TR4, i.e. $0.5 \mathrm{~Sv}$, is on the continental margin (above $120 \mathrm{~m}$, longitude superior to $42.82^{\circ} \mathrm{N}$ ). This probably gives a lower estimation of $\mathrm{NCb} 1$ intrusion. Otherwise, by difference between NC flux upstream (TR4) and downstream (TR3) of the intrusion, a higher flux value of $1.2 \mathrm{~Sv}$ is obtained. This NCb1 northern branch is not detected on transect TR3, since TR3 does not extend close enough to the coast (shallowest depth $\sim 800 \mathrm{~m}$ ). In the northern part of transect $\mathrm{AD}, \mathrm{NCb} 1$ is not detected close to the surface but can be traced at depth below $40 \mathrm{~m}$ (Fig. 3b,c). The main branch of the NC crosses transect TR3 going southwest. Then, on transect $\mathrm{AD}$, it splits again in a main branch (going west at the surface, and southwest at depth, Fig. 3), and a second northern intrusion (b2, Fig. 6b), detailed in the next section.

3.1.1.3. Bathymetry influences. The NC can be affected by the bathymetry, as the two following examples show. The northern edge of the Grand Rhone canyon, which extends to the $2500 \mathrm{~m}$ isobath, influences the $\mathrm{NC}$ below $120 \mathrm{~m}$ on transects TR3 and AD (Fig. 3d). CTD 47, performed between $\mathrm{AD}$ and TR3, shows two pycnoclines, one approximately at $40 \mathrm{~m}$ and a second one at 100-120 m depth (Raimbault, 2000). This confirms the hypothesis that the bathymetry influence can be felt on the currents as far up in the water column as this one is homogeneous. The second example is further west. From $40 \mathrm{~m}$ down to $300 \mathrm{~m}$, the $\mathrm{NC}$ is split by the southern edge of the Grand Rhone canyon (transect AD; Fig. 3b,d). The NC southern portion goes to the southwest $\left(220^{\circ}\right)$ but most of this branch is probably southward of transect $\mathrm{AD}$. Its northern section (b2) goes to the northwest $\left(300^{\circ}\right)$, approximately into the Grand Rhone canyon. These directions remain constant from $40 \mathrm{~m}$ down to the ADCP detection limit. CTD 46 (Raimbault, 2000) performed before transect AD showed a strong pycnocline at $40 \mathrm{~m}$. The rather well-mixed water column below it allows the influence of the bathymetry to be felt up to this $40 \mathrm{~m}$ pycnocline. Above $40 \mathrm{~m}$, the NC does not split and continues westward (Fig. 6b).

Canyons also have a strong influence on the deep portions of the NC. Branches of the NC were observed going up through canyons to the right of the NC direction. During transects TR1, TR2, and GI, deep currents went north in the Planier canyon, the Petit Rhone canyon, and the Montpellier canyon (data not shown). Bottom currents also went up the Aude canyon going northwest (e.g., transect PQ; Fig. 3b,d).

3.1.1.4. South of the NC. Southeast of the GoL, most of transects TR3 and TR4 are done over water columns deeper than $2500 \mathrm{~m}$. Those two transects are the only ones of that cruise to collect data seaward of the NC. Apart from the NC, their most noticeable feature is an eastern undercurrent. This current flows at depths below $50 \mathrm{~m}$. It is located south of $42.55^{\circ} \mathrm{N}$ for TR3 and south of $42.45^{\circ} \mathrm{N}$ for TR4 (Fig. 5).

Table 2

Same as Table 1 for Moogli 3. Transect TQ has been completed from north to south, in reverse direction to the Moogli 2 transect QT. The XYZ "loop" includes transects $\mathrm{XY}, \mathrm{YZ}_{1}, \mathrm{Z}_{1} \mathrm{Z}_{2}$

\begin{tabular}{lllllll}
\hline Transect & Day (01/99) & Time & Position start & Position end & Wind direction & Wind strength \\
\hline AD & $11-12$ & $21: 07-4: 16$ & $42^{\circ} 40-5^{\circ} 08$ & $43^{\circ} 15-5^{\circ} 08$ & N, NW & 25 \\
EH & $12-13$ & $20: 36-3: 54$ & $42^{\circ} 40-4^{\circ} 45$ & $43^{\circ} 15-4^{\circ} 45$ & W & $15 /$ weaker \\
LI & $13-14$ & $20: 44-4: 21$ & $43^{\circ} 12-4^{\circ} 13$ & $42^{\circ} 30-4^{\circ} 22$ & N, NE & $25 ;$ weaker south LI \\
TQ & $14-15$ & $20: 41-4: 44$ & $43^{\circ} 01-3^{\circ} 20$ & $42^{\circ} 20-3^{\circ} 45$ & NE & 25 (idem) \\
UM & $15-16$ & $22: 02-5: 18$ & $43^{\circ} 07-3^{\circ} 48$ & $42^{\circ} 25-4^{\circ} 04$ & N & 15 \\
XYZ & $19-20$ & $17: 46-4: 50$ & $42^{\circ} 00-5^{\circ} 00$ & $42^{\circ} 25-4^{\circ} 45$ & N, NE & 10 \\
TR5 & 20 & $15: 34-19: 44$ & $42^{\circ} 30-5^{\circ} 01$ & $42^{\circ} 57-5^{\circ} 46$ & N, NE & $10-15$ \\
\hline
\end{tabular}



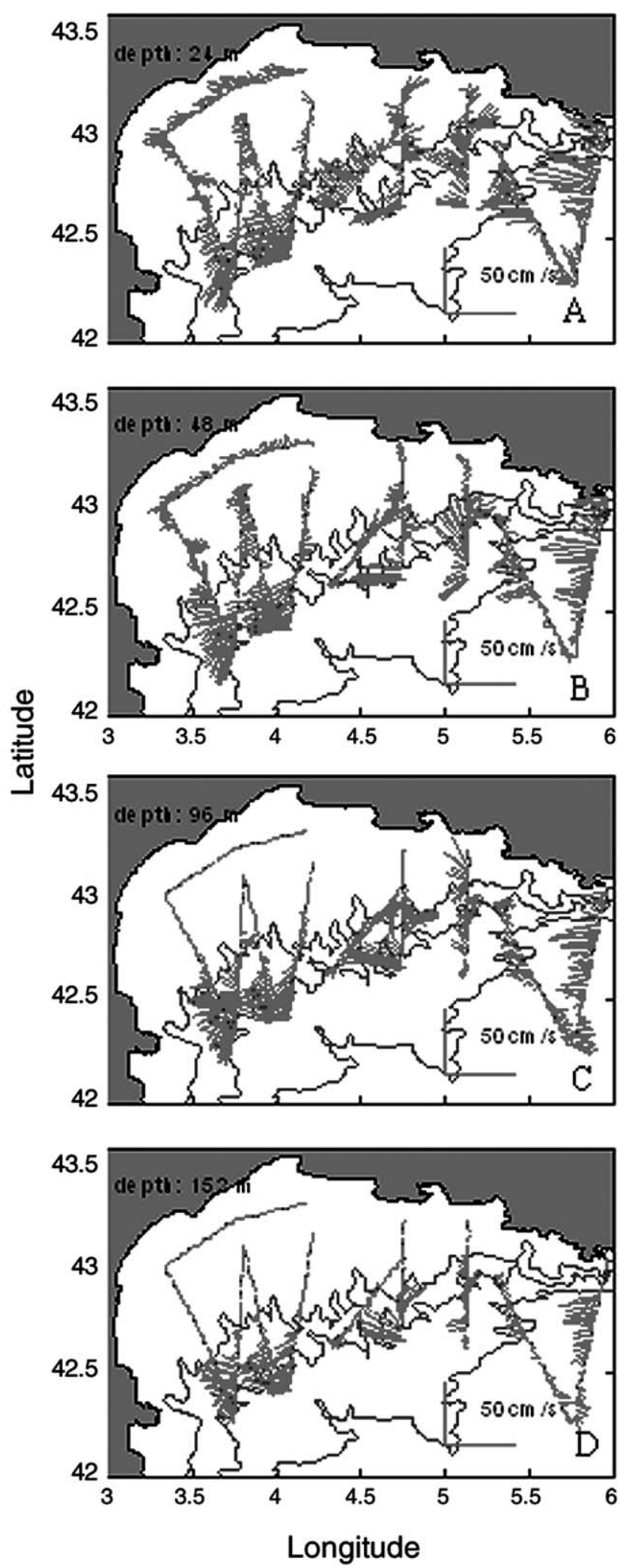

Fig. 3. Horizontal currents during Moogli 2 at (A) $24 \mathrm{~m}$, (B) $48 \mathrm{~m}$, (C) $96 \mathrm{~m}$, and (D) $152 \mathrm{~m}$, along the transects detailed in Fig. 2b. Same isobaths as on Fig. 2.

Such eastern current was also observed south of the NC during the Billion 1996 summer cruise (Lapouyade and Durrieu de Madron, 2001).

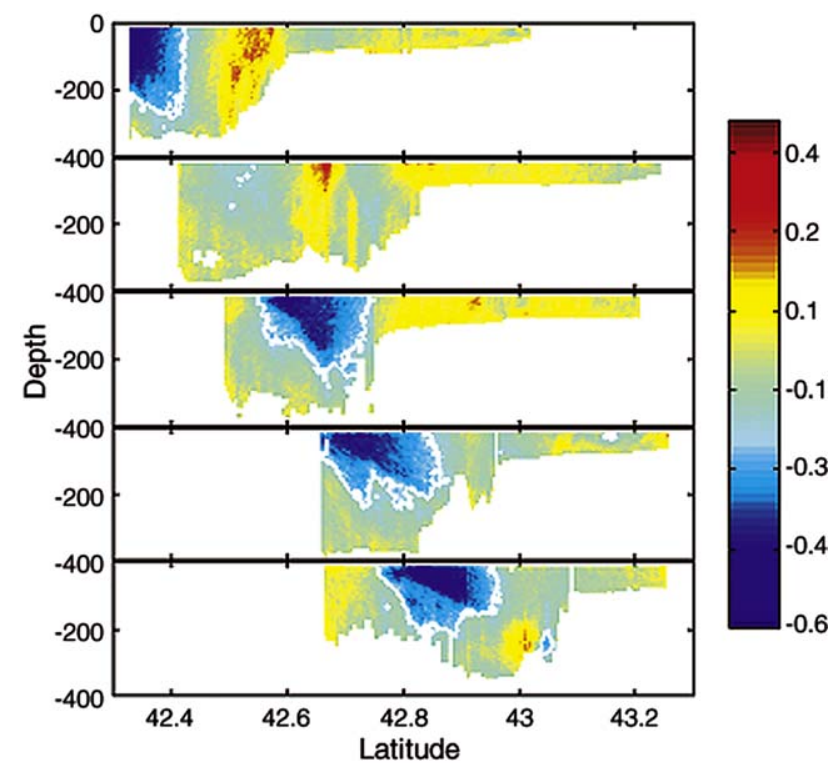

Fig. 4. Vertical sections of the west-east current component along transects AD, EH, LM, MP and QT (bottom to top) during Moogli 2. Extreme values measured on these transects are -0.5 and $0.25 \mathrm{~m} \mathrm{~s}^{-1}$. Color scale (speed in $\mathrm{m} \mathrm{s}^{-1}$ ) ranges from -0.6 to $0.5 \mathrm{~m} \mathrm{~s}^{-1}$, to allow comparison with Moogli 3 sections (Fig. 14). Contours at $-0.20 \mathrm{~m} \mathrm{~s}^{-1}$ (white) show the NC core limits.

\subsubsection{Main currents in the continental shelf}

The main circulation features are detailed for two periods: (a) early June 6-late June 8 in the western part of the GoL and (b) June 17-19 in the eastern part. To follow the NC flow, it would be more logical to present data first in the eastern GoL, and second in the western GoL. But, since nearly $10 \mathrm{~d}$ separate these two data sets, they are presented in chronological order. Moreover, a strong counter-circulation is observed on the shelf from west to east, so that this order is also meaningful hydrodynamically.

3.1.2.1. Circulation in the western GoL (a). While the NC roughly follows the continental slope with its core above the $1000 \mathrm{~m}$ isobath, an eastern current (E1) can be clearly followed along the $100 \mathrm{~m}$ isobath (Fig. 6a). More inland, despite relatively shallow waters ( $25 \mathrm{~m}$ depth in average north of $42.8^{\circ} \mathrm{N}$ and west of $\left.3.5^{\circ} \mathrm{E}\right)$, strong currents $\left(20 \mathrm{~cm} \mathrm{~s}^{-1}\right)$ are detected going northwest and west (current W1) (Fig. 6a). The continental shelf currents W1 and E1 may constitute an "elongated" cyclonic gyre, as was found in modeling outputs under specific tramontane conditions. Indeed, during this part of the cruise, winds were coming from the west and north-west (10-30 knots, Table 1) and were localized in the western part of the gulf (Aladin data for June 7, not shown). This kind of wind conditions, used as inputs in the Symphonie 3D oceanographic model, lead to a clear cyclonic gyre circulation in the western part of the gulf (Estournel et al., 2003). Unfortunately, this cyclonic circulation hypothesis cannot be checked since no current measurements were made in the directions orthogonal to the arrows. 
Table 3

The horizontal width $(\mathrm{km})$ and thickness $(\mathrm{m})$ of the NC, and the latitude of its core are given for each cruise. Width with an * indicates that the southern end of the $\mathrm{NC}$ was not reached during the cruise; so this width underestimates the real width of the NC

\begin{tabular}{lllllll}
\hline & \multicolumn{3}{c}{ Moogli 2} & \multicolumn{3}{l}{ Moogli 3} \\
Transect & Width & Thickness & Latitude & Width & Thickness & Latitude \\
\hline AD & 39 & $0-120$ & 42.78 & 31 & $0-250$ & 42.84 \\
EH & $28^{*}$ & $0-200$ & 42.66 & $31 *$ & $0-300$ & 42.69 \\
LI-LM & 39 & $0-200$ & 42.57 & 29 & $0-300$ & 42.60 \\
MP-UM & 33 & $0-240$ & 42.53 & 24.5 & $0-250$ & 42.52 \\
QT-TQ & 33 & $0-125$ & 42.67 & $17 *$ & $0-325$ & 42.33 \\
\hline
\end{tabular}

3.1.2.2. Circulation in the eastern GoL (b). At the top of the continental slope (depth range: $200-500 \mathrm{~m}$ ), an eastern current (E2) can be followed, from west to east, on transects GI, KE, EU, AD and TR3 (Fig. 6b). Whether or not it is a continuation of E1 is uncertain because of the nearly $10 \mathrm{~d}$ interval between the western and eastern coverage of the GoL. Part of the northwestern branch of the NC (b2) detected on transect $\mathrm{AD}$ is probably deviated and entrained east by $\mathrm{E} 2$. Closer to the coast, a small anticyclonic circulation spreads mostly in the longitude direction. Its northern branch (E3) entrains Rhone River waters to the east. West of Marseilles $\left(43.2^{\circ} \mathrm{N}-5.2^{\circ} \mathrm{E}\right)$, the three water masses: E2, entrained $\mathrm{NC}$, and Rhone waters E3 (and potentially a fourth one: the first northern branch of the NC) mix. Due to the coast boundary to the north and east, these waters are obliged to go westward, closing the southern branch of the small anticyclonic gyre (W2). But W2 is squeezed between the northern branch of the anticyclonic gyre (E3) and the eastern current (E2). There is not enough place for all the mixed waters to go back west at the surface; so part of the waters are obliged to sink and go west at depth (Fig. 3, $48 \mathrm{~m}$ ). At the surface, Rhone waters are of the lowest density $\left(\sigma=26-27 \mathrm{~kg} \mathrm{~m}^{-3}\right)$; E2 waters are also relatively light $\left(\sigma=27 \mathrm{~kg} \mathrm{~m}^{-3}\right)$; while mixed waters $\sigma$ are $\sim 28.5 \mathrm{~kg} \mathrm{~m}^{-3}$. Hence, the mixed waters sink to go westward. They probably mix with waters from the NC branch that has intruded at the eastern entrance of the GoL (see section above). These waters can be traced from $40 \mathrm{~m}$, down to $200 \mathrm{~m}$ on transect AD (Fig. 4).

This circulation in the eastern part of the GoL is clearly seen on the SeaWiFs satellite image of June 19, 1998 (Fig. 7). In the eastern part of the GoL, there is a typical Sanskrit "Om" shape of high chlorophyll concentration waters (0.8-1.5 $\mu \mathrm{g} 1^{-1}$ compared to the background of $\left.0.4 \mu \mathrm{g} 1^{-1}\right)$. The top portion of the Om symbol corresponds mainly to the Rhone River waters forming the anticyclonic gyre; the bottom portion to the main branch of the NC.

\subsubsection{Inertial currents}

3.1.3.1. Detecting the inertial currents. A combination of phase unwrapping (Chereskin et al., 1989) and current direction analysis is a good technique to exhibit the presence of inertial currents. The unwrapped phase of the current shear (16-72 $\mathrm{m})$ shows three periods where its slope is negative and $\sim-f_{0}$ : June 14 , early June 16 (transects TR1 and TR2), end of transect GI on June 17 (Fig. 8). Analyzing the currents throughout the water column during these three periods show that inertial currents are detected during the last two periods. Indeed, three transects show inertial currents: transects TR1, TR2, and UI (Table 1). They were collected at the beginning of the second part of the Moogli 2 cruise, hence just after the storm obliged the R/V Le Suroît to go back to the coast for protection. During the storm, the mistral and tramontane blew very strongly on June 11-13 (Aladin data). On June 13, the second part of the cruise started. The Suroit stayed mostly in shallow waters (less than $100 \mathrm{~m}$ deep) until June 15 and no inertial waves were detected during that period. Then the R/V crossed the GoL back and forth (transects TR1 and TR2), approximately along the $1000 \mathrm{~m}$ isobath. During three portions (I1, I2, I3) of these transects, the currents in the surface layer (roughly $0-50 \mathrm{~m}$ ) and at depth (below $60 \mathrm{~m}$ ) are $\sim 180^{\circ}$ out-of-phase (Fig. 9). In stratified waters, this is characteristic of wind-induced horizontal inertial currents.

Transect GI crosses the continental shelf in a southwestern direction (Table 1, Fig. 2). The vertical section of the current amplitude exhibits two zones of strong current $(|\mathrm{V}|>$ $20 \mathrm{~cm} \mathrm{~s}^{-1}$ ), one at the surface (down to $40 \mathrm{~m}$ ) and the other deeper (50-90 m) (Fig. 10). The surface current goes to the west and the deeper layer to the northeast. This baroclinic structure is particularly strong at the end of the transect, between station I and $42.95^{\circ} \mathrm{N}$. No CTD station was done at station I. A CTD station (CTD 45), done at G, the northeastern end of transect GI, shows the pycnocline at $25 \mathrm{~m}$ (Raim-

Table 4

For certain transects of Moogli 2 (from east to west), flux of the NC (in Sv), flux incertitude between parentheses, surface used for the flux calculation (in km²), flux per unit surface (in $\mathrm{Sv} / \mathrm{km}^{2}$ ), mean direction of the NC core, latitude extent and depth range of the NC

\begin{tabular}{llllllll}
\hline Transect & Flux (incertitude) & Surface & Flux/surface & Direction & Latitude south & Latitude north & Depth range \\
\hline TR4 & $2.0(0.3)$ & 14.28 & 0.14 & $280^{\circ}$ & 42.5 & 43.7 & $16-384$ \\
TR3 & $0.8(0.2)$ & 8.18 & 0.09 & $245^{\circ}$ & 42.57 & 42.88 & $16-256$ \\
AD & $0.4(0.1)$ & 4.95 & 0.08 & $280^{\circ}$ & 42.67 & 42.83 & $16-384$ \\
MP & $1.5(0.2)$ & 8.47 & 0.18 & $250^{\circ}$ & 42.42 & 42.67 & $16-408$ \\
\hline
\end{tabular}




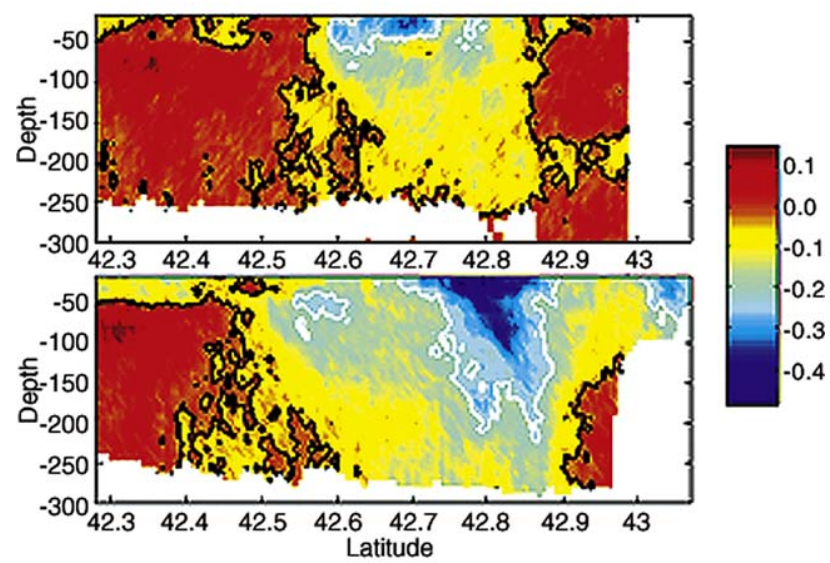

Fig. 5. Vertical sections of the west-east current component along transects (A) TR1 and (B) TR2 during Moogli 2. Extreme values for TR1 are -0.35 and $0.15 \mathrm{~m} \mathrm{~s}^{-1}$, and, for TR2, -0.5 and $0.15 \mathrm{~m} \mathrm{~s}^{-1}$. A common color scale, in $\mathrm{m}^{-1}$, is used to allow comparison between the two transects. Contours at $-0.20 \mathrm{~m} \mathrm{~s}^{-1}$ (white) show the NC core limits, and at $0 \mathrm{~m} \mathrm{~s}^{-1}$ (black) the limits between the $\mathrm{NC}$ and eastern currents.

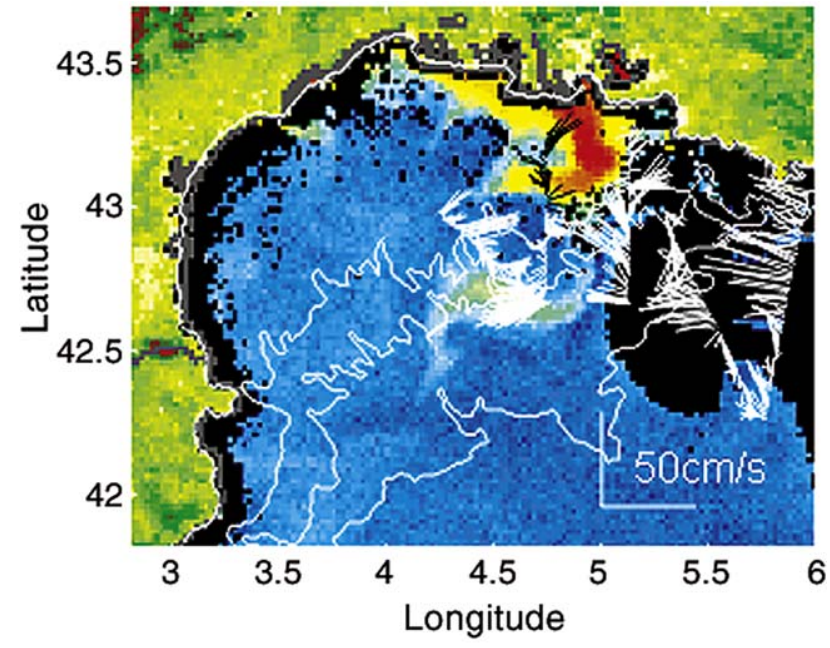

Fig. 7. SeaWiFs map of chlorophyll-a concentration on June 19, 1998 (pixel resolution $\sim 1 \mathrm{~km}$ ). Blue represents $0.2 \mu \mathrm{g} \mathrm{l}^{-1}$, green $1 \mu \mathrm{g} \mathrm{l^{-1 }}$, and red more than $10 \mu \mathrm{g} \mathrm{l}^{-1}$ of chl-a. High turbidity leads to an overestimation of chl-a in the Rhône plume; hence color scale is not shown. ADCP currents measured during June 17-19 are shown in white, and in black in the Rhone River plume. Isobaths at 200, 1000, and $2000 \mathrm{~m}$ are drawn in white.
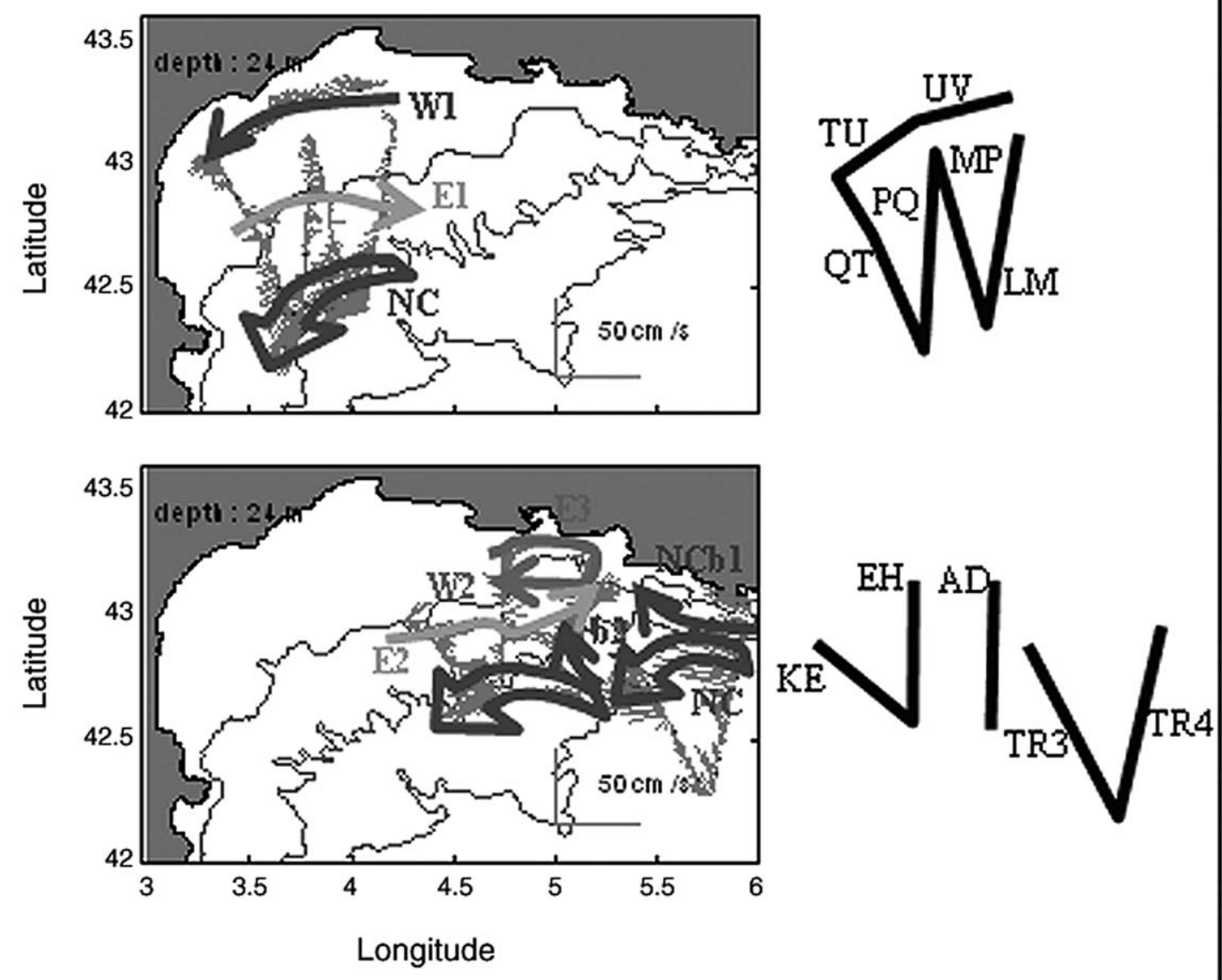

Longitude

Fig. 6. Main current directions represented on top of the measured horizontal currents at $24 \mathrm{~m}$, during two periods (A) June 6-8 in the western part of the GoL and (B) June 17-19 in the eastern part. The main branch of the NC is represented with double-line arrows; branches of the NC intruding on the gulf, or continental shelf currents with single-line arrows. For clarity, names of the transects are reminded on the right. 


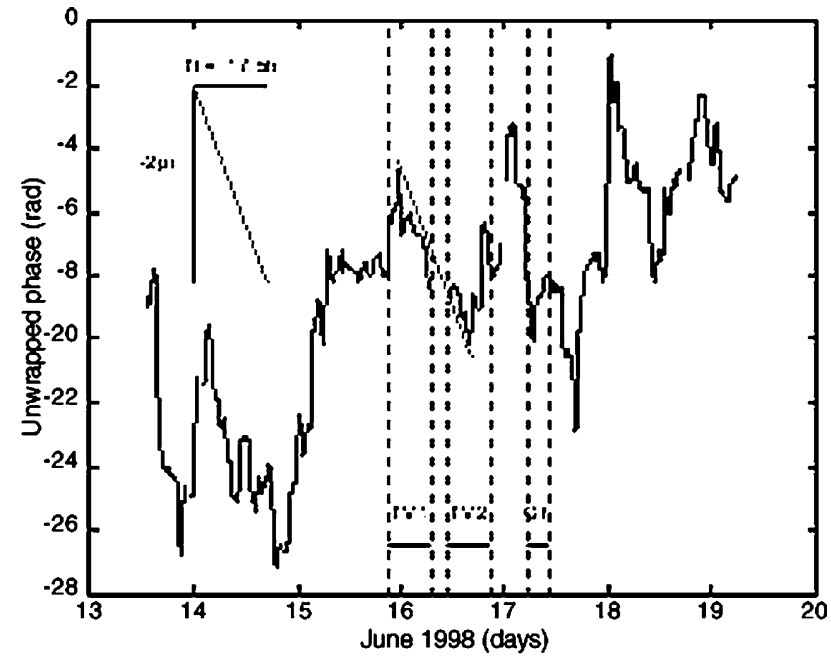

Fig. 8. Phase unwrapping of the horizontal current shear (16-72 m) during June 13-19. The negative slope corresponding to the Coriolis factor is shown. Transects TR1, TR2 and GI were done during the periods indicated by vertical dotted lines.

bault, 2000). The pycnocline is shallower than the $40 \mathrm{~m}$ expected from the baroclinic feature located southwest of the CTD. Nonetheless the deepest current structure shallows going northeast towards G (Fig. 10). This means that the pycnocline is tilted towards the surface going northeast. And

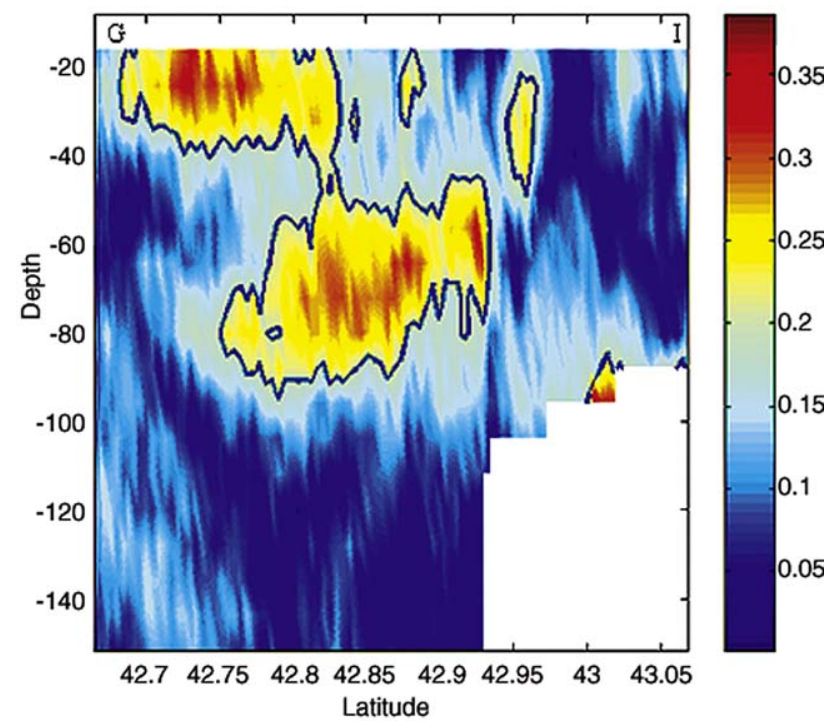

Fig. 10. Vertical section of the horizontal current amplitude along transect GI during Moogli 2. Color scale is the speed amplitude in $\mathrm{m} \mathrm{s}^{-1}$.

the current shear corresponds, as expected, to the pycnocline depth.

East of transect GI, at the (FIxed Observation Station) SOFI mooring $\left(43.07^{\circ} \mathrm{N}, 5.13^{\circ} \mathrm{E}, 162 \mathrm{~m}\right.$ depth $)$, time series of current measurements were continuously collected at two
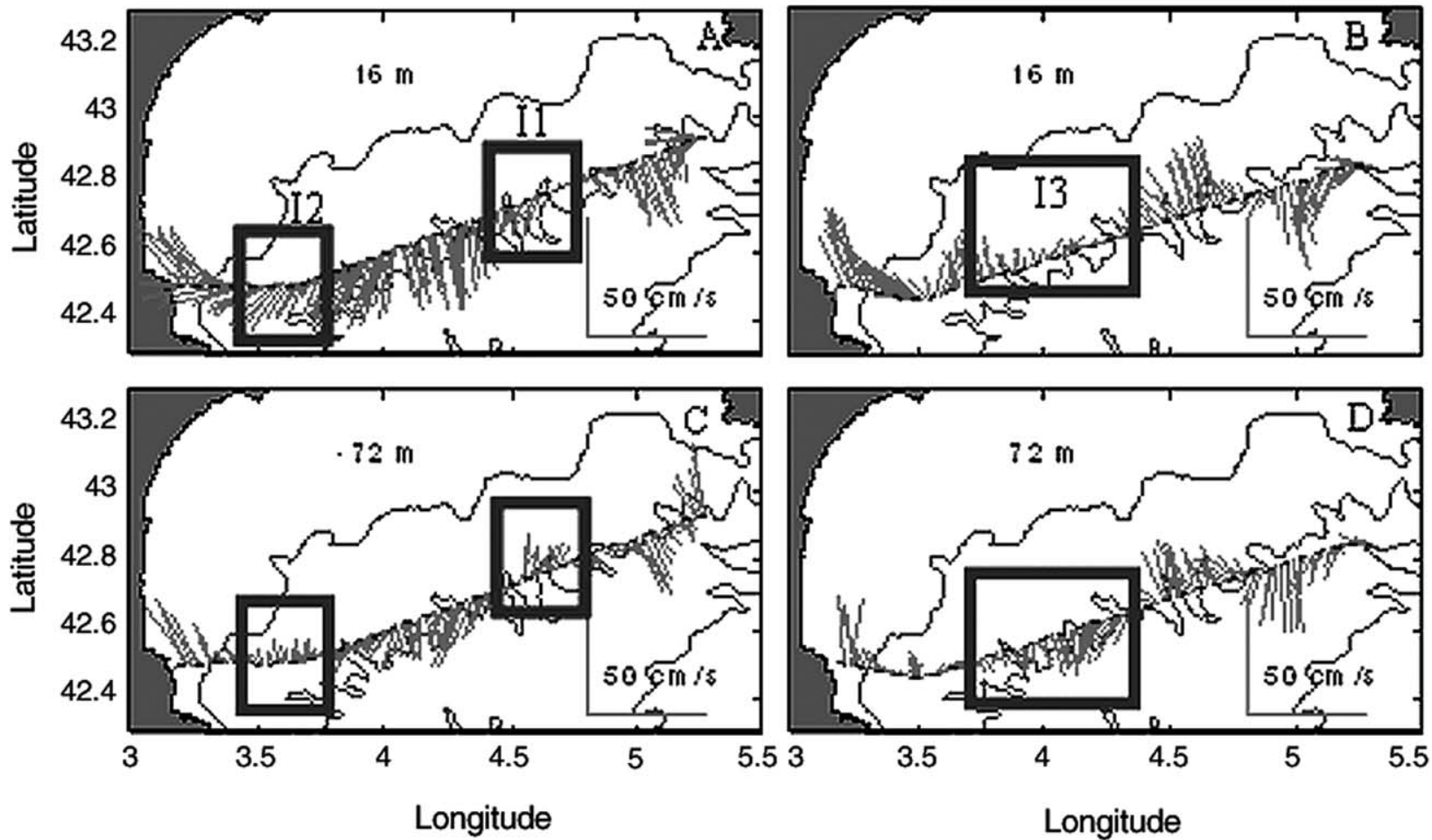

Fig. 9. Horizontal currents during Moogli 2 at (A) $16 \mathrm{~m}$ and (C) $72 \mathrm{~m}$ along transect TR1, and (B) $16 \mathrm{~m}$ and (D) $72 \mathrm{~m}$ along transect TR2. The boxes isolate the zones with inertial currents. At $16 \mathrm{~m}$, they are labeled (I1, I2, and I3) in the chronological order currents were measured. Isobaths 100, 1000, and 2000 m are shown. 

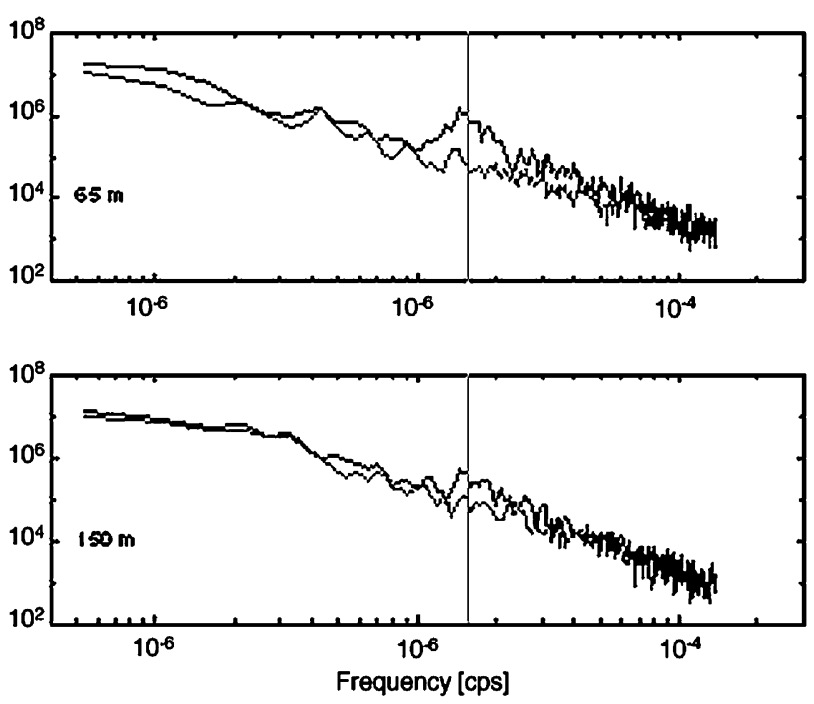

Fig. 11. Rotary spectra vs. frequency (bottom $x$-axis) for (A) $65 \mathrm{~m}$, (B) $150 \mathrm{~m}$ currents measured at SOFI during April-June 1998. The black (grey) line is the clockwise (counter-clockwise) component of the spectra. Note that, at the inertial frequency (indicated by the vertical line), the clockwise component is much higher than the counter-clockwise component.

depths $(65$ and $150 \mathrm{~m}$ ) during that period. At both depths, during April-June 1998, the rotary spectra of the current time series clearly show, at the Coriolis frequency, a clockwise component much stronger than the counter-clockwise component (Fig. 11). This is characteristic of inertial currents. Phase unwrapping of the mooring currents also shows a specific inertial episode on June 14-15 (data not shown).

3.1.3.2. Quantifying the inertial currents. Several techniques are used to check the time evolution of these inertial currents and quantify their contribution to the circulation, assuming horizontal coherence. This is not a trivial issue since current measurements are acquired with both time and space variability.

At the GoL latitude, the Coriolis factor $f_{0}$ corresponds to a period of about $17.5 \mathrm{~h}$. Plotting $u(t)=\cos \left(f_{0}\right)=\sin \left(f_{0} t+\pi / 2\right)$ on the eastward component and $v(t)=\sin t\left(f_{0} t\right)$ on the northward component of the current exhibits the clockwise rotation of the inertial oscillation with time (Fig. 12). The mean current of the eastward component is around $-10 \mathrm{~cm} \mathrm{~s}^{-1}$, corresponding to the average westward speed of the NC. The mean component of the northward component is zero. The amplitude of the sinusoidal curve, corresponding to the inertial current, is about $20 \mathrm{~cm} \mathrm{~s}^{-1}$. Hence, at that depth $(16 \mathrm{~m})$, the speed of the inertial oscillation can be locally as high as $200 \%$ the NC speed. Otherwise, the average speed of the NC in its core is about $30 \mathrm{~cm} \mathrm{~s}^{-1}$; so the inertial current is about $2 / 3$ the NC. It is important to remember that the thickness of the top layer of the inertial oscillation is about $30 \mathrm{~m}$ while the NC extends over $200 \mathrm{~m}$; hence, the inertial oscillation energy is much smaller than the NC energy.

The presence of inertial currents can also be verified on the spatial maps of TR1 and TR2 currents. For example,
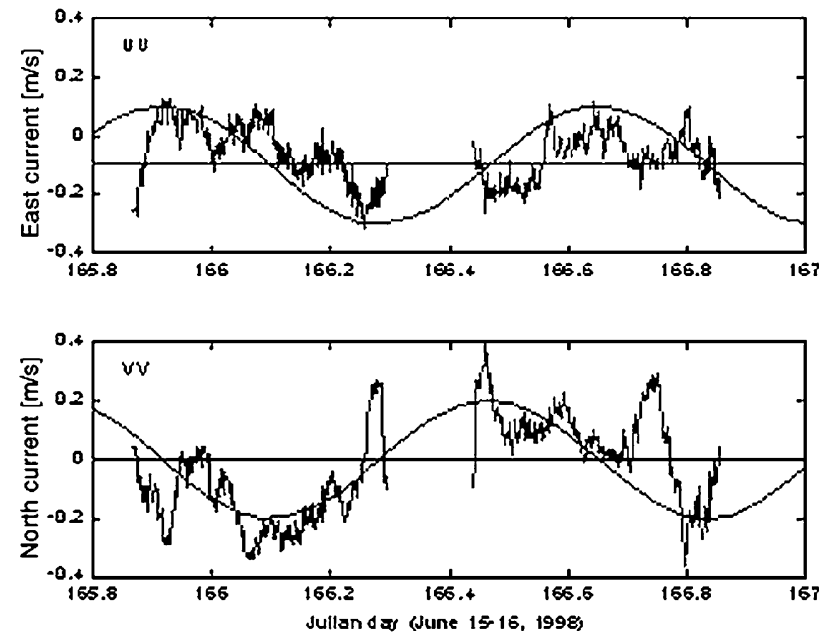

Fig. 12. Time series of the (A) west-east and (B) south-north current components, at $16 \mathrm{~m}$ depth, along transects TR1 and TR2 of Moogli 2. Superimposed is a sinusoidal curve of inertial period, shifted by $+\pi / 2$ on (A) compared to (B). The means of the two components are also drawn: (A) $-0.10 \mathrm{~m} \mathrm{~s}^{-1}$ and (B) $0 \mathrm{~m} \mathrm{~s}^{-1}$.

surface inertial currents are oriented southwestward at the end of TR1 (12) and northward in the center of TR2 (13), about $10 \mathrm{~h}$ after (Fig. 9 and Table 1). A full rotation of $360^{\circ}$ representing $17.5 \mathrm{~h}$, it is expected that the inertial currents rotate by $126^{\circ}$ (taking into account the geostrophic component of the NC) clockwise in $10 \mathrm{~h}$. The observed clockwise rotation is $\sim 120^{\circ}$, in nearly perfect agreement with the one calculated. The inertial currents compared are separated by 50-75 km. This shows that our horizontal coherence assumption was acceptable. No coherence is found between I1 and $\mathrm{I} 2$, or between I1 and I3.

\subsection{Moogli 3}

During the beginning of the cruise, the fresh water inputs from the Rhone River were low for the season. Then they increased rapidly and stayed high (above $3000 \mathrm{~m}^{3} \mathrm{~s}^{-1}$ ) from January 18 to the end of the cruise. During the cruise, the wind blew mostly from the north (mistral), oscillating to a tramontane or northeast/east wind. It was always stronger than 10 knots. There was a storm with strong east winds during January 16-17.

Current data are shown at four different depths throughout the GoL (Fig. 13). From east to west, the five transects AD to TQ were done at nights, one each night from January 11 to 16 (Table 2). This temporal spacing does not provide a real synoptic view of the gulf. But since there is neither discontinuities nor apparent contradictions in the main current directions during this period, it will be studied as a whole.

\subsubsection{The Northern Current (NC)}

3.2.1.1. Characteristics. During Moogli 3, the strongest currents reach $70 \mathrm{~cm}^{-1}$ at $40 \mathrm{~m}$ depth. Below, currents decrease with depth, but are still between 20 and $40 \mathrm{~cm} \mathrm{~s}^{-1}$ at $160 \mathrm{~m}$ 

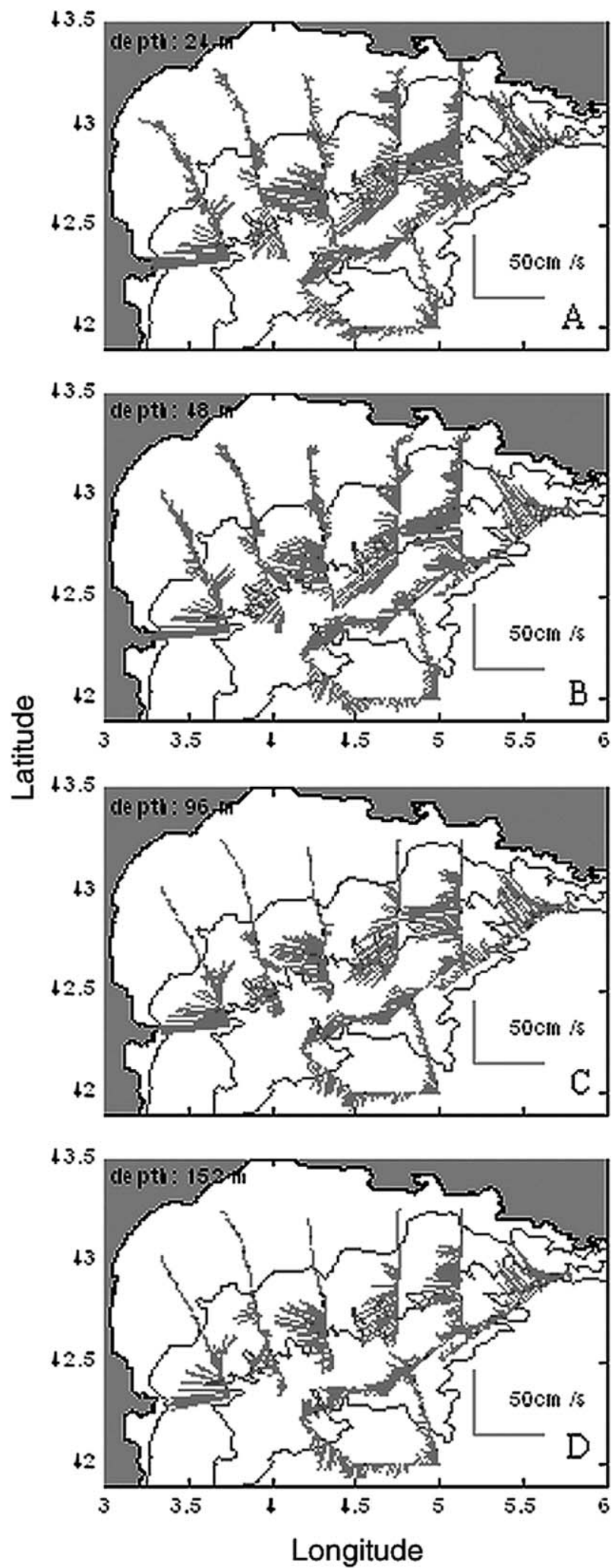

Fig. 13. Horizontal currents during Moogli 3 at (A) 24 m, (B) 48 m, (C) $96 \mathrm{~m}$, and (D) $152 \mathrm{~m}$, along the transects detailed in Fig. 2d, and the same isobaths.

depth. The strongest currents are located along the continental slope and correspond to the core of the NC. This core is 200-280 m deep (Fig. 14; Table 3). The width of the NC is

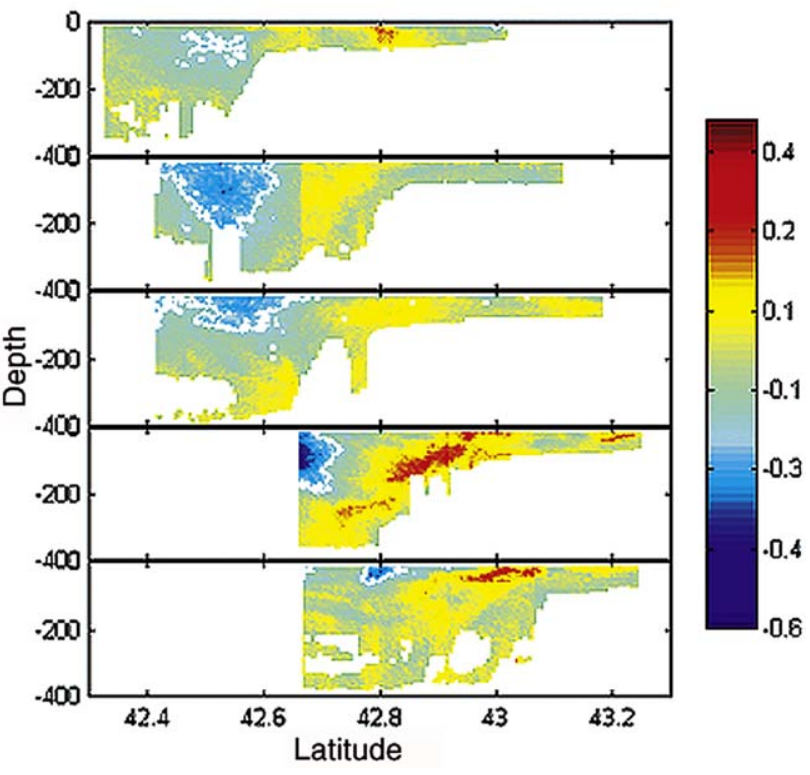

Fig. 14. Vertical sections of the west-east current component along transects AD, EH, LI, PM and TQ (bottom to top) during Moogli 3. Color scale is in $\mathrm{m} \mathrm{s}^{-1}$. Contours at $-0.20 \mathrm{~m} \mathrm{~s}^{-1}$ (white) show the limits of the NC core.

between 25 and $35 \mathrm{~km}$. Its core is not symmetrical with depth. Its southern limit is tilted northward with depth. Its flux is $\sim 2.1 \mathrm{~Sv}$ east of the GoL, and between 1.7 and $1.8 \mathrm{~Sv}$ along the continental slope of the GoL (Table 5).

At the surface, the signature of the NC is clearly associated with sharp gradients of temperature and salinity. Crossing the $\mathrm{NC}$ from south to north, temperature increases and salinity drops (Fig. 15). Indeed the NC is the northern branch of a cyclonic gyre; hence it flows north of an isopycnal dome with colder and saltier (hence denser) waters to its south, and warmer and fresher waters to its north.

3.2.1.2. Ramifications. The main branch of the NC is clearly present along the continental slope, between isobath $1500 \mathrm{~m}$ (to the south) and isobath $200 \mathrm{~m}$ (to the north). Its main direction is westward, but going either southwest (southern portions of transects $\mathrm{AD}, \mathrm{EH}$ and $\mathrm{UM}$ ) or northwest (southern portions of transects LI and TQ). A branch of the NC splits from the main current at the entrance of the GoL and enters in the eastern region of the gulf. It is clearly visible along TR5, and, close to the coast, between the isobaths 100 and $200 \mathrm{~m}$, on transects AD and EH (Figs. 13 and 14). By difference between the NC fluxes, the intrusion may account for $0.4 \mathrm{~Sv}$ (Table 5). The NC splits again just west of transect LI. The southern branch or "main" branch of the NCcontinues along the continental slope meandering to the southwest on UM and to the northwest on TQ (as described above). While the northern branch-intrusion of the $\mathrm{NC}$ in the GoL-goes first northwest on UM, and then southwest on TQ.

3.2.1.3. Bathymetry effects. Along transect TR5, the edge between the Marseilles and the Grand Rhone canyons splits the $\mathrm{NC}$ in two. Both branches of the $\mathrm{NC}$ go roughly in the same direction $\left(315-320^{\circ}\right)$ but are clearly split, from the 
Table 5

Same as Table 4 for Moogli 3

\begin{tabular}{|c|c|c|c|c|c|c|c|}
\hline Transect & Flux (precision) & Surface & Flux/surface & Direction & Latitude south & Latitude north & Depth range \\
\hline TR5 & $2.1(0.2)$ & 9.7 & 0.21 & $320^{\circ}$ & 42.75 & 42.95 & $16-400$ \\
\hline $\mathrm{AD}$ & $1.7(0.2)$ & 8.6 & 0.19 & $260^{\circ}$ & 42.69 & 43.01 & $16-352$ \\
\hline LI & $1.8(0.2)$ & 11.8 & 0.15 & $275^{\circ}$ & 42.49 & 42.75 & $16-384$ \\
\hline
\end{tabular}

surface to the ADCP detection limit, by a zone of much weaker currents. This bottom feature, responsible for the split of the NC, is clearly visible on the $2000 \mathrm{~m}$ isobath, and is about $5 \mathrm{~km}$-wide along transect TR5. In fact, this edge can already be detected on the $2500 \mathrm{~m}$ isobath (about $95 \mathrm{~km}$ east). Due to its geographical extent and to the homogeneity of the water column (CTD station performed at the southwestern end of transect TR5, CTD \#48 of (Raimbault, 2000), the influence of this edge is strongly felt by the $\mathrm{NC}$ up to the surface.

A circulation feature opposed to the $\mathrm{NC}$ is detectable between the coast and the $\mathrm{NC}$ above La Ciotat canyon. Currents going southeast (in opposition to all other currents in the zone) were detected at all depth (Fig. 13). They correspond to a current following the canyon and going offshore, in the opposite direction to the year-averaged current found in that canyon (Albérola and Millot, 2003). Modeling studies reproduce well this current counter to the NC.

\subsubsection{Hydrodynamic features on the continental shelf}

3.2.2.1. Main currents. The continental circulation is mostly westward on the eastern side of the GoL, apart from eastern currents close to the coast, similar to the ones observed during the summer cruise.

On the western side of the GoL, a strong eastern countercurrent is detected on transects UM and TQ between the two branches of the NC (see above). It goes northeast on TQ, but southeast on UM, maybe deviated from its northern path by the strong intrusion of NC. This counter-current has speed higher than $30 \mathrm{~m} \mathrm{~s}^{-1}$, and extends down to the ADCP detec-
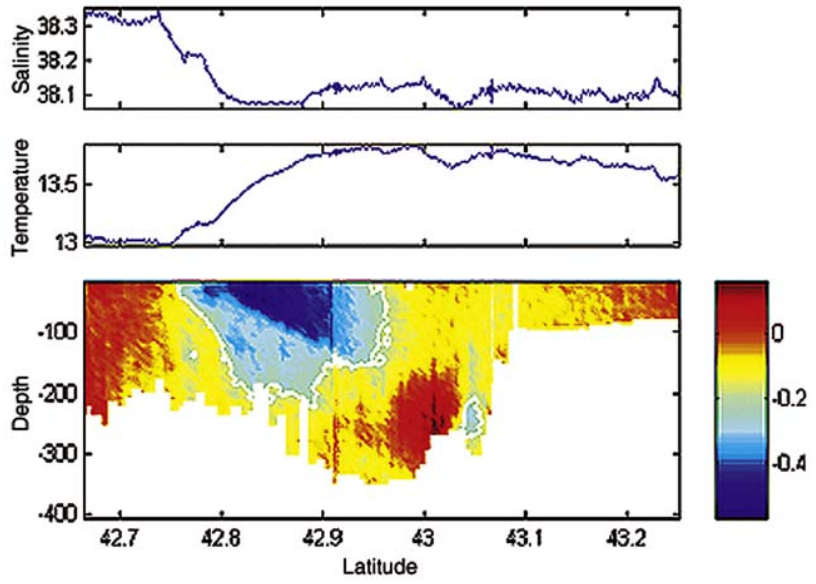

Fig. 15. (A) Surface salinity, (B) surface temperature, and (C) vertical section of the west-east current component (color scale in $\mathrm{m} \mathrm{s}^{-1}$, with contours at $-0.20 \mathrm{~m} \mathrm{~s}^{-1}$ shown in white) along transect AD of Moogli 3 . tion limit (around $300 \mathrm{~m}$ ). Another southeast current, weaker but wider than the previous one, is located north of the $\mathrm{NC}$ intrusion on transect UM (Fig. 13A and B).

3.2.2.2. Formation of dense waters on the continental shelf. The water column is completely homogeneous at station $\mathrm{T}$ $\left(43.02^{\circ} \mathrm{N}-3.33^{\circ} \mathrm{E}\right.$; depth $\left.=60 \mathrm{~m}\right)$. The temperature was the coldest $\left(T=11.7{ }^{\circ} \mathrm{C}\right)$ recorded throughout the cruise, and density was high $(28.8$; with $S=37.8)$ for surface $(0-50 \mathrm{~m})$ waters. The station was done at the end of January 14 (20:40) so night cooling could not have been responsible for this cooling. The very cold water may have been due to intense evaporation; the wind-mainly from the north-having blown over 20 knots throughout the day. Stations S (January 14, 22:52) and $\mathrm{R}$ (January 15, 1:05), made after station $\mathrm{T}$, going south along transect TQ, also exhibited homogeneous and dense waters throughout the water column $(\sigma=28.9-$ 28.95). During Moogli 3, no other stations on the continental shelf exhibited such conditions (homogeneity, very cold temperatures, and high density).

This is interpreted as a formation of dense cold water on the continental shelf, as was observed in 1969 (Fieux, 1973), or in 1971 (Person, 1974). Indeed, during these cruises, it was shown that these coastal waters reached high density $(\sigma=28.9)$ due to their very cold temperature $\left(9.5-11^{\circ} \mathrm{C}\right)$, and despite moderate salinity (37.8-37.9) (Fieux, 1974).

Arrival of very cold waters were detected at a mooring in the Lacaze-Duthiers canyon on February 14, 1999 (Bethoux et al., 2002). Stations T, S, and R are located just north of this canyon. If these cold waters originate from the dense waters observed at station $\mathrm{T}$ a month earlier, they would have propagated at about $2 \mathrm{~cm} \mathrm{~s}^{-1}$. This speed is much smaller than the $60 \mathrm{~cm} \mathrm{~s}^{-1}$ speed measured at the $1000 \mathrm{~m}$ mooring simultaneously with the arrival of cold dense waters (Bethoux et al., 2002). But this high speed probably only occurred in the canyon.

\subsubsection{Chimney of dense waters offshore}

Offshore data were collected along a southern "loop" (XYZ) during January 19 and 20 (Fig. 13). Offshore currents are homogeneous from the surface down to $300 \mathrm{~m}$. Currents are oriented to the southwest, apart at station Z1, station X and north of it. This roughly cyclonic circulation takes place around a "chimney", associated with the formation of Western Mediterranean Deep Water (Chu, 1991; Gascard, 1973, 1991; Madec and Crepon, 1991a). Stations Y and Z2 exhibit completely homogeneous profiles in temperature, salinity (and hence density) from the surface down to $1000 \mathrm{~m}$ (CTDs 
43 and 45; Raimbault, 2000). These stations must have been done in some of the mixing plumes of the chimney (Schott et al., 1996).

\section{Discussion}

\subsection{Variations of the $\mathrm{NC}$}

\subsubsection{Seasonal variations}

The NC has weaker maximum speeds, is more extended horizontally, and is more shallow in summer (Moogli 2) than in winter (Moogli 3) (Figs. 4 and 14). Its vertical shape is also very different between the two seasons. During the winter, the $\mathrm{NC}$ is strongly inclined to the north following the sharp isopycnes associated with the cyclonic gyre, which is close to the shelf-break. While, in summer, the isopycnes are not as steep and are located more to the south, further from the slope. That explains that the summer $\mathrm{NC}$ is shallower and more extended in width than the winter $\mathrm{NC}$, and that it does not have the striking vertical tilt observed during the winter. In fact, a reverse angle is even observed on transect $\mathrm{AD}$ of Moogli 2. There, the shallow core of the NC is inclined to the south with depth, probably due to the strong eastern current flowing on the shelf below the NC (Fig. 4). Offshore of the Ebro delta, a slightly inclined tilt of the NC was observed in June 1987 in agreement with tilted haloclines (Font et al., 1995).

The ADCP fluxes do not agree with the previously observed seasonal variations of the $\mathrm{NC}$ (references listed in the introduction). Indeed, east of the GoL, the NC flux is $\sim 2 \mathrm{~Sv}$ both in winter and summer; while a lower summer flux was excepted. Precision in ADCP measurements induces an incertitude of maximum $0.3 \mathrm{~Sv}$ in these flux estimations. Nonetheless, in summer, the fluxes may be biased by inertial oscillations. Geostrophic and ADCP fluxes cannot be directly compared since they are obtained with different techniques. Geostrophic calculation does not include the barotropic component present in the ADCP flux. The geostrophic technique has also been used for the two Moogli cruises. But no CTD stations were done on most of the transects selected here; so no comparison and retrieval of the potential inertia contribution are possible. The high ADCP flux in June may not be representative of the seasonal NC flux; or it may correspond to an episode of higher flux, such as the ones previously observed in April 92 (Conan and Millot, 1995) or in July 1985 (Sammari et al., 1995). Indeed, mesoscale activity is sometimes quite high in late spring or early summer, as was observed 1 year (1989) out of a 5 year-long study (Font et al., 1995). The study of the NC variability would benefit from additional experimental measurements including a network of moorings and systematic ADCP transects across the $\mathrm{NC}$ for several years.

\subsubsection{Meanders of the $N C$}

The NC meanders along the shelf break. If meanders are defined from crest to crest as a wave would be, half- wavelength represents the distance between two nodal points of the wave. During Moogli 3, two meanders with a halfwavelength of $\sim 35 \mathrm{~km}$ were observed. Flexas et al. (2002) countered four meanders (transforming into intrusions) at the beginning of April 1997. During Moogli 2, the separate coverage of the eastern and western part of the GoL makes it difficult to assess the number of meanders.

The hypothesis that meanders location could be linked to the presence of canyons cutting the continental slope, is tested in the following paragraph. Indeed, the relative vorticity of a moving water mass can be modified at the passage over a canyon (vertical stretching). This vorticity change can create deviations in the current directions (Gill, 1982). Current meanders were observed along the Catalan coast where canyons are regularly positioned (about every $50 \mathrm{~km}$ ) and interpreted as due to the change of vorticity over these canyons (Arnau del Amo, 2000). Here, the canyons do not generate meanders since, at the same locations, the NC can have different directions. For example, along transect EH, the $\mathrm{NC}$ is going northwest during Moogli 2 and southwest during Moogli 3. Also, if the meanders of the $\mathrm{NC}$ were to follow the local bathymetry of the canyons, the $\mathrm{NC}$ would be expected to go, for example, northwest in the canyons on transects $\mathrm{EH}$ and UM. But during Moogli 3, the NC goes southwest on the southern portions of transects EH and UM (Fig. 13). To explain these meanders, another possibility is to disregard the presence of all canyons, and only keep the main orientation of the isobaths. From east to west, the expected curvature of the NC would then be a gradual change in directions (western to southern current), which is not observed on either cruises. Since the situation is more complicated than either of these two cases (with or without canyons), other factors than strictly bathymetry influence the path of the NC.

Echevin et al. (2003) found that a coastal baroclinic current deeper than a shelf break would create, upon arriving at the shelf break, first a fast propagating barotropic/ baroclinic double Kelvin wave system, then a baroclinic wave slowly propagating along the shelf break. This second wave, slower than a classical coastal Kelvin wave, propagates along the shelf break and takes approximately $3 \mathrm{~d}$ to cross from Marseilles to Spain. Along the shelf, its direction oscillates from southwest to northwest at about $1 \mathrm{~d}$ interval (Fig. 8c,d of Echevin et al., 2003). The fluctuations of the NC during Moogli 3 are identical to the modeled ones. Since Moogli 3 took place in winter, when the NC goes down to $300 \mathrm{~m}$ while the shelf depth is about $100 \mathrm{~m}$, the model hypotheses correspond exactly to the cruise conditions. The position of the meanders of the NC are interpreted as the propagating baroclinic wave.

\subsection{Intrusions of the NC in the GoL}

Echevin et al. (2003) wrote that "when the density stratification is weak and the pycnocline deep, the shelf topography can act as a barrier and prevent the current from flowing into the gulf. When the stratification is strong and shallow, 
the current may separate into two branches, one flowing along the shelf break and the other following the coast".

\subsubsection{On the eastern side}

The entrance of the $\mathrm{NC}$ in the gulf at its eastern side is first considered. The situations observed during Moogli 2 and 3 are more complex than the one described by Echevin et al. (2003), and the wind forcing cannot be neglected. During Moogli 2, while there is a strong and shallow stratification and winds from the northeast, the NC probably makes an intrusion, detected below $40 \mathrm{~m}$ on the northern portion of transect AD. The flux of the intrusion is probably comprised in a $0.4-1.2 \mathrm{~Sv}$ range. During Moogli 3, the stratification is weak, the water column nearly or completely homogeneous and the winds from the north to northeast. An intrusion of the $\mathrm{NC}$ is clearly detected on the eastern side of the GoL and spreads from the slope up to the $100 \mathrm{~m}$ isobath. The flux of the intrusion is estimated at $\sim 0.4 \mathrm{~Sv}$.

\subsubsection{Along the shelf break}

During Moogli 2, no intrusions of the NC are detected on the continental shelf elsewhere than at the eastern entrance of the gulf. In the western part of the gulf, while a strong north-northwest wind is blowing, a cyclonic circulation dominates on the continental shelf. The forcing prevents the $\mathrm{NC}$ intrusions could be the wind, or a balanced water budget in the gulf. Modeling should shed light on whether one of these two factors dominate. During Moogli 3, intrusions of the $\mathrm{NC}$ are observed in the center of the gulf (transect LI) and on its western side (transect TQ). Weak north to northeast winds are blowing during both transects. Only portions of the current enter the gulf since the current is deeper than the continental shelf. The strong eastern current observed in the eastern GoL may be due to these intrusions.

Hence, in opposition to Echevin et al. (2003) statement, no conclusion on $\mathrm{NC}$ intrusions could come only from the state of the water column stratification. Indeed, there are globally more intrusions of the NC in the gulf during Moogli 3 than Moogli 2. Three reasons could be responsible: (1) the NC is closer to the coast during the winter and hence its northwest meanderings necessarily intrude on the gulf; (2) intrusions are favored by east or northeast winds, and there are more favorable winds during Moogli 3 than Moogli 2; (3) the global balance of the gulf during Moogli 3 could be a water "deficit" (Estournel et al., 2003), hence favoring the intrusions of the NC. But the Rhone River input was higher than $3000 \mathrm{~m}^{3} \mathrm{~s}^{-1}$ on the days preceding transect TR5, and that did not prevent the strong intrusion of the $\mathrm{NC}$ on the shelf during that transect. So the third reason may be neglected in this case. Modeling results concerning these two periods should soon determine the respective contributions of these factors (Dylan-Julliand, personal communication).

\subsection{Topographic effects on surface currents}

The edge between the Marseilles and the Grand Rhone canyon divides the NC in two, from the bottom up to $120 \mathrm{~m}$ depth during Moogli 2, and through the whole water column during Moogli 3. The upper limit of this topographic influence corresponds to the depth of a deep pycnocline, when it exists. This stresses the role of the homogeneity of the bottom part of the water column. The deep bathymetry can affect currents as far up as the water column is not stratified.

On the contrary, the influence of the southern edge of the Grand Rhone canyon on the currents was clear only during Moogli 2 and not visible during Moogli 3. The reason is that the NC is located north of that edge in the latter case (winter), and hence could not be separated by that edge.

\section{Summary and conclusions}

During both cruises, the NC is clearly detected along the continental slope and intrudes on the eastern side of the shelf. East of the gulf, its flux is $\sim 2 \mathrm{~Sv}$ both in June and January. This new result does not agree with the expected lower intensity of the NC in the summer. The present flux, based on ADCP measurements, is not directly comparable with geostrophic estimations. Nonetheless, it is recommended to monitor the NC variability with a network of moorings and systematic cross-current ADCP transects for several years. That should shed light on its variability and whether this one is linked with deep water formation, as supported by numerical (Madec et al., 1991b) and theoretical studies (Crepon et al., 1989), or other processes (Béthoux et al., 1988).

The NC characteristics exhibit seasonal differences. Some agree with observations previously described in the literature. During the summer, the NC is generally wider than $35 \mathrm{~km}$, shallow $(\sim 200 \mathrm{~m})$, with maximum currents of $40-50 \mathrm{~cm} \mathrm{~s}^{-1}$. During the winter, the NC is narrower $(28 \mathrm{~km})$ but deeper $(250-300 \mathrm{~m})$ than during the summer. Its maximum speed is around $70 \mathrm{~cm} \mathrm{~s}^{-1}$. Other characteristics are new or were not as clearly shown previously. The tilted vertical structure of the NC is observed only during the winter, in agreement with the more pronounced cyclonic dome structure of that season. During the winter, meanders of the NC are interpreted as due to baroclinic instabilities propagating along the shelf break. Other circulation features are also season-specific. During the 1999 winter, dense water formations are observed both on the continental shelf and offshore. During Moogli 2, an eastern current was observed at the top edge of the continental slope. Whether it is characteristic of the season is not determined. The summer stratification allows the development, after strong wind variations, of inertial currents with their characteristic 2-layer baroclinic structure. In the surface layer, the speed of the inertial oscillation can locally be as high as $200 \%$ the NC speed. Otherwise the inertial current is about $2 / 3$ the NC. Horizontal spatial coherence of inertial currents is found on scales up to $50-75 \mathrm{~km}$. The contribution of these inertial currents to the measured circulation cannot be neglected but is hard to estimate without the detailed and local analysis done in this article. The situation is different with time series data sets where high frequency motions such as inertial currents are classically 
filtered out. Spatial interpolation technique (Candela et al., 1992) was tried unsuccessfully on the Moogli 1 ADCP data to isolate inertial currents (Durrieu de Madron, personal communication). The retrieval of the inertial component from the circulation is one of the main problems that oceanographers and modelers, working on the circulation in the GoL and elsewhere, are presently dealing with.

Other hydrodynamic features depend primarily on topography or wind forcing. During both cruises, the NC is found to branch out with deep portions going up canyons. Otherwise, bathymetric features strongly influence currents as far up as no pycnocline is encountered. Intrusions of the $\mathrm{NC}$ on the continental shelf occur at the eastern end of the GoL during both cruises, hence apparently independently of the stratification conditions. Moreover, intrusions also occur at the center and western end of the gulf during Moogli 3. The winter (more northern) position of the NC seems to favor these intrusions on the continental shelf. But the wind curl stress probably also influences the existence and strength of these intrusions of the $\mathrm{NC}$ on the continental shelf. The continental shelf circulation is complex. During Moogli 3, strong eastern counter-currents may be linked to the numerous intrusions of the NC on the shelf. During Moogli 2, tramontane conditions seem to favor the formation of a cyclonic structure on the western continental shelf. Modeling studies should use the present data to validate or contradict the hypotheses made on the mechanisms generating the circulation features described in this article.

\section{Acknowledgements}

This study was accomplished in the framework of the Programme National d'Environnement Côtier (PNEC), Chantier Golfe du Lion. I thank the captains and crews of the Suroit, the chief scientist Patrick Raimbault, and Gérard Eldin for his assistance with Codas. I have very much appreciated the reviews from, or discussions with Frédéric Diaz, Claude Estournel, Claire Dylan-Julliand, Yann Leredde, Claude Millot, Louis Prieur, and Isabelle Taupier-Letage. I am grateful to Virginie Destuynder for her collaboration, and to Urania Christaki for her friendship during Moogli 3. The SeaWiFs image was obtained on the Italy/JRC site.

\section{References}

Albérola, C., Millot, C., 2003. Circulation in the French Mediterranean coastal zone near Marseilles: influence of the wind and of the Northern Current. Cont. Shelf Res. 23 (6), 587-610.

Albérola, C., Millot, C., Font, J., 1995. On the seasonal and mesoscale variabilities of the Northern Current during the PRIMO-0 experiment in the western Mediterranean Sea. Oceanol. Acta 18 (2), 163-192.

Arnau del Amo, P.A., 2000. Aspectos de la variabilidad de mesoescala de la circulacion marina en la plataforma continental catalana. Polytechnic University of Catalunya Tesis doctoral.
Bethoux, J.P., Durrieu de Madron, X., Nyffeler, F., Taillez, D., 2002. Deep water in the western Mediterranean: peculiar 1999 and 2000 characteristics, shelf formation hypothesis, variability since 1970 and geochemical inferences. J. Mar. Syst., 33-34 117-131.

Béthoux, J.-P., Prieur, L., Bong, J.H., 1988. Le courant Ligure au large de Nice. Oceanol. Acta 9, 56-67 (special issue).

Candela, J., Beardsley, R.C., Limeburner, R., 1992. Separation of tidal and subtidal currents in ship-mounted acoustic Doppler current profiler observations. J. Geophys. Res. 97 (C1), 769-788.

Castellon, A., Font, J., Garcia, E., 1990. The Liguro-Provençal-Catalan current (NW Mediterranean) observed by Doppler profiling in the Balearic Sea. Sci. Mar. 54 (3), 269-276.

Chereskin, T.K., Levine, M.D., Harding, A.J., Regier, L.A., 1989. Observations of near-inertial waves in acoustic Doppler current profiler measurements made in the mixed layer dynamics experiment. J. Geophys. Res. 94 (C6), 8135-8145.

Chu, P.C., 1991. Geophysics of deep convection and deep water formation in the oceans. In: Chu, P.C., Gascard, J.C. (Eds.), Deep Convection and Deep Water Formation in the Oceans, vol. 57. Elsevier Oceanography Series, pp. 3-16.

Conan, P., Millot, C., 1995. Variability of the northern current off Marseilles, western Mediterranean Sea, from February to June 1992. Oceanol. Acta 18 (2), 193-205.

Crepon, M., Boukthir, M., Barnier, B., Aikman III, F., 1989. Horizontal ocean circulation forced by deep water formation: Part I. An analytical study. J. Phys. Oceanogr. 19, 1781-1792.

Crepon, M., Wald, L., Monget, J.M., 1982. Low-frequency waves in the Ligurian Sea during December 1977. J. Geophys. Res. 87 (C1), 595600.

Cruzado, A., Velasquez, Z.R., 1990. Nutrients and phytoplankton in the Gulf of Lion, northwestern Mediterranean. Cont. Shelf Res. 10 (9-11), 931-942.

Echevin, V., Crepon, M., Mortier, L., 2003. Interaction of a coastal current with a gulf: application to the shelf circulation of the Gulf of Lion in the Mediterranean Sea. J. Phys. Ocean. 33, 188-206.

Estournel, C., Durrieu de Madron, X., Marsaleix, P., Auclair, F., Julliand, C., Vehil, R., 2003. Observation and modelisation of the winter coastal oceanic circulation in the Gulf of Lion under wind conditions influenced by the continental orography (FETCH experiment). J. Geophys. Res. 108 (c3), 8059.

Fieux, M., 1973. Contribution à l'étude hydrologique et dynamique du Golfe du Lion en période hivernale. Union des Océanographes de France 5 (2), $38-43$.

Fieux, M., 1974. Formation d'eau dense sur le plateau continental du Golfe du Lion. Colloques Internationaux du CNRS. La Formation des Eaux Océaniques Profondes. CNRS, Paris.

Flexas, M., Durrieu de Madron, X., Garcia, M.A., Canals, M., Arnau, P., 2002. Flow variability in the Gulf of Lion during the MATER HFF Experiment (March-May 1997). J. Mar. Syst., 33-34 197-214.

Font, J., Garcia-Ladona, E., Gorriz, E.G., 1995. The seasonnality of the mesoscale motion of the Northern Current of the western Mediterranean: several years of evidence. Oceanol. Acta 18 (2), 207-219.

Gascard, J.-C., 1973. Vertical motions in a region of deep water formation. Deep-Sea Res. 20, 1011-1027.

Gascard, J.-C., 1991. Open ocean convection and deep water formation revisited in the Mediterranean, Labrador, Greenland and Weddell Seas. In: Chu, P.C., Gascard, J.C. (Eds.), Deep Convection and Deep Water Formation in the Oceans, vol. 57. Elsevier Oceanography Series, pp. 157-182.

Gill, A.E., 1982. In: Donn, W.L. (Ed.), Atmosphere-Ocean Dynamics. Academic Press, pp. 662.

Joyce, T., 1989. On in situ "calibration" of shipboard ADCPs. J. Atmos. Ocean. Tech. 6, 169-172.

Lacombe, H., Tchernia, P., 1960. Quelques traits généraux de l'hydrologie méditerranéenne d'après diverses campagnes hydrologiques récentes en Méditerranée, dans le proche Atlantique et dans le détroit de Gibraltar. Cahiers Océanographiques 12 (8), 527-537. 
Lacombe, H., Tchernia, P., 1972. Caractères hydrologiques et circulation des eaux en Méditerranée. In: Stanley, D.J. (Ed.), The Mediterranean Sea. Dowden Hutchinson and Ross, Strousberg, pp. 25-36.

Lapouyade, A., Durrieu de Madron, X., 2001. Seasonal variability of the advective transport of particulate matter and associated organic carbon in the Gulf of Lion (NW Mediterranean). Oceanol. Acta 24, 295-312.

Madec, G., Crepon, M., 1991a. Thermohaline-driven deep water formation in the Northwestern Mediterranean sea. In: Chu, P.C., Gascard, C. (Eds.), Deep Convection and Deep Water Formation in the Oceans, vol. 57. Elsevier Oceanography Series, pp. 241-266.

Madec, G., Chartier, M., Delecluse, P., Crepon, M., 1991b. Effect of thermohaline forcing variability on deep water formation in the Western Mediterranean Sea: a high resolution three dimensional numerical study. Dyn. Atmos. Oceans 15 (3-5), 301-332.

Millot, C., 1982. Analysis of upwelling in the Gulf of Lion. In: Nihoul (Ed.), Hydrodynamics of Semi-enclosed Seas.

Millot, C., 1990. The Gulf of Lion's hydrodynamics. Cont. Shelf Res. 10 (9-11), 885-894.

Millot, C., 1991. Mesoscale and seasonal variabilities of the circulation in the Western Mediterranean. Dyn. Atmos. Oceans 15, 179-214.

Millot, C., 1999. Circulation in the Western Mediterranean Sea. J. Mar. Syst. $20,423-442$.

Millot, C., Crepon, M., 1981. Inertial oscillations on the Continental Shelf of the Gulf of Lion-observations and theory. J. Phys. Oceanogr. 11 (5), 639-657.
Millot, C., Wald, L., 1980. The effects of Mistral wind on the Ligurian current near Provence. Oceanol. Acta 3 (4), 399-402.

Moutin, T., Raimbault, P., Golterman, H.L., Coste, B., 1998. The input of nutrients by the Rhône river into the Mediterranean Sea: recent observations and comparison with earlier data. Hydrobiologia 373/374, 237-246.

Person, R., 1974. Un exemple de descente des eaux superficielles du plateau continental dans un canyon du Golfe du Lion. CNRS. Processus de formation d'eaux océaniques profondes. Colloques Internationaux du CNRS, Paris.

Pollard, R., Read, J., 1989. A method for calibrating shipmounted acoustic Doppler profilers and the limitations of Gyro. Compasses. J. Atmos. Ocean. Tech. 6, 859-865.

Raimbault, P., 2000. MOOGLI, Recueil de données. LOB, COM, Marseille, pp. 271.

Sammari, S., Millot, C., Prieur, L., 1995. Aspects of the seasonal and mesoscale variabilities of the Northern Current in the western Mediterranean Sea inferred from PROLIG-2 and PROS-6 experiments. DeepSea Res. I 42 (6), 893-917.

Schott, F., Visbeck, M., Send, U., Fischer, J., Stramma, L., Desaubies, Y., 1996. Observations of deep convection in the Gulf of Lion, Northern Mediterranean, during the winter of 1991-92. J. Phys. Ocean 26 (4), 505-524. 